\title{
A novel antagonist of TRPM2 and TRPV4 channels: Carvacrol
}

\author{
Mustafa Nazıroğlu' ${ }^{1,2} \mathbb{B}$
}

Received: 27 August 2021 / Accepted: 5 December 2021 / Published online: 6 January 2022

(c) The Author(s), under exclusive licence to Springer Science+Business Media, LLC, part of Springer Nature 2022

\begin{abstract}
The overload cytosolic free $\mathrm{Ca}^{2+}\left(\mathrm{cCa}^{2+}\right)$ influx-mediated excessive generation of oxidative stress in the pathophysiological conditions induces neuronal and cellular injury via the activation of cation channels. TRPM 2 and TRPV4 channels are activated by oxidative stress, and their specific antagonists have not been discovered yet. The antioxidant and anti-Covid-19 properties of carvacrol (CARV) were recently reported. Hence, I suspected possible antagonist properties of CARV against oxidative stress (OS)/ADP-ribose (ADPR)-induced TRPM2 and GSK1016790A (GSK)-mediated TRPV4 activations in neuronal and kidney cells. I investigated the antagonist role of CARV on the activations of TRPM2 and TRPV4 in SH-SY5Y neuronal, BV-2 microglial, and HEK293 cells. The OS/ADPR and GSK in the cells caused to increase of TRPM2/TRPV4 current densities and overload cytosolic free $\mathrm{Ca}^{2+}\left(\mathrm{cCa}^{2+}\right)$ influx with an increase of mitochondrial membrane potential, cytosolic (cROS), and mitochondrial (mROS) ROS. The changes were not observed in the absence of TRPM2 and TRPV4 or the presence of $\mathrm{Ca}^{2+}$ free extracellular buffer and PARP-1 inhibitors (PJ34 and DPQ). When OS-induced TRPM2 and GSK-induced TRPV4 activations were inhibited by the treatment of CARV, the increase of cROS, mROS, lipid peroxidation, apoptosis, cell death, $\mathrm{cCa}^{2+}$ concentration, caspase -3 , and caspase -9 levels were restored via upregulation of glutathione and glutathione peroxidase. In conclusion, the treatment of CARV modulated the TRPM2 and TRPV4-mediated overload $\mathrm{Ca}^{2+}$ influx and may provide an avenue for protecting TRPM2 and TRPV4-mediated neurodegenerative diseases associated with the increase of mROS and $\mathrm{cCa}^{2+}$.
\end{abstract}

Keywords Carvacrol $\cdot$ Glutathione $\cdot$ Neurodegeneration $\cdot$ Oxidative stress $\cdot$ TRPM $2 \cdot$ TRPV4

\section{Abbreviations}

a.u. arbitrary unit

ADPR ADP-ribose

$\mathrm{BF} \quad$ bright field

$\mathrm{Ca}^{2+} \quad$ calcium ion

CARV carvacrol

CASP-3 caspase -3

CASP-9 caspase -9

$\mathrm{CCa}^{2+} \quad$ cytosolic free calcium ion

cROS cytosolic reactive oxygen species

GSH glutathione

GSHPx glutathione peroxidase
GSK GSK1016790A

LSCM laser scan confocal microscope

MDA malondialdehyde (lipid peroxidation)

mROS mitochondrial reactive oxygen species

PI propidium iodide

ROS reactive oxygen species

RuRe ruthenium red

TRP transient receptor potential

TRPM2 transient receptor potential melastatin 2

TRPV4 transient receptor potential vanilloid 4

$\Delta \Psi \mathrm{m}$ mitochondrial membrane depolarization
Mustafa Nazıroğlu

mustafanaziroglu@sdu.edu.tr

1 Drug Discovery Unit, BSN Health, Analyses, Innovation, Consultancy, Organization, Agriculture and Trade Ltd, Isparta TR-32260, Turkey

2 Departments of Biophysics and Neuroscience, Faculty of Medicine, Suleyman Demirel University, Isparta TR-32260, Turkey

\section{Introduction}

Oxidative stress contains several reactive oxygen species (ROS) such as superoxide and hydroxyl radicals. The generation of ROS is induced during several physiological systems such as phagocytic activity and mitochondria ATP generation (Halliwell 2006; Nazıroğlu 2007). The generations of cytosolic (cROS) and mitochondrial ROS (mROS) 
induce several adverse actions to the cell membrane and cellular components such as nucleic acids, lipids, and proteins. Hence, the generations of cROS and mROS have essential roles in the etiology of several neurodegenerative diseases, including Alzheimer' disease and Parkinson' disease (de la Monte et al. 2000; Islam 2017; Nazıroğlu et al. 2020) and viral diseases, including Covid-19 (Saleh et al. 2020). The generations of cROS and mROS are scavenged by the antioxidants such as glutathione (GSH) and glutathione peroxidase (GSHPx) (Dringen 2000; Takata et al. 2020; Nazıroğlu et al. 2020). Mitochondria via the increase of mitochondrial membrane potential $(\Delta \Psi \mathrm{m})$ act as main sources on the generations of ROS in several cells and neurons. Accumulation of calcium ion $\left(\mathrm{Ca}^{2+}\right)$ into mitochondria induces the increase of $\Delta \Psi \mathrm{m}$ in several body cells. In turn, the increase of $\Delta \Psi \mathrm{m}$ results in the generation of cROS and mROS, and also apoptosis and cell death via the increases of caspase -3 (CASP-3) and caspase -9 (CASP -9). By the feedback mechanisms, the excessive generation of mROS induces overload $\mathrm{Ca}^{2+}$ influx via the activation of calcium channels (Espino et al. 2010; Malko et al. 2021). Hence, the modulation of calcium channels diminishes the increase of cellular oxidative cytotoxicity and apoptosis in several cells (Espino et al. 2010; Carrasco et al. 2018).

In the cells, several physiological and pathophysiological functions are induced by the increase of cytosolic free $\mathrm{Ca}^{2+}\left(\mathrm{cCa}^{2+}\right)$ concentration. The $\mathrm{Ca}^{2+}$ passes the cell membrane via the activation of cation channels. A member of the cation channels is transient receptor potential (TRP) superfamily. There are 30 members such as the TRP melastatin 2 (TRPM2) and TRP vanilloid 4 (TRPV4) in the TRP superfamily (Carrasco et al. 2018). TRPM2 channel has a redox sensitive enzyme, namely ADP-ribose (ADPR) pyrophosphatase in the NUDT9 domain (Perraud et al. 2001; Fonfria et al. 2004). Hence, the ROS and ADPR induce TRPM2 activator action in several cells (Hara et al. 2002; Nazıroğlu and Lückhoff 2008). There is no specific blocker of TRPM2. Some chemicals such as ACA and 2-APB are nonspecific antagonists of TRPM2 (Nazıroğlu et al. 2012; Carrasco et al. 2018). The antagonists of TRPM2 induce some adverse actions to the cells and neurons, and some of these irreversibly block the channel (Nazıroğlu 2007; Nazıroğlu et al. 2012). TRPV4 has a physiological sensor for temperature, osmotic pressure, and mechanical deformation (Watanabe et al. 2002; Carrasco et al. 2018). The TRPV4 channel is activated by several stimuli, including GSK1016790A (GSK), although it is inhibited by ruthenium red (RuRe) (Watanabe et al. 2002; Nakagawa et al. 2020). In addition, the excessive generation of mROS induces the activation of TRPV4 (Badr et al. 2016). In the human coronary artery endothelial cells, the treatment of GSK increased the generation of ROS (Bubolz et al. 2012). The protective actions of ROS scavengers (Trolox and ARL- 17,477) on the
GSK-induced neuronal death and apoptosis in the hippocampus were recently reported (Hong et al. 2016). Although the physiological function of TRPV4 in neurons is preliminarily clarified, no study is available about the effects of naturel antioxidants on the activation of TRPV4 in neurons and cells.

Plant extracts potentially have rich antioxidant contents, and they are potential sources of new drug discoveries. Natural drugs from the plant extracts have modulator potential actions on several processes such as free radicals and $\mathrm{Ca}^{2+}$ influx (Chen et al. 2015; Naeem et al. 2021). Carvacrol (CARV) is extracted as an essential oil from the plants (Thymbra, Origanum, Satureja, and Thymus). The CARV has modulator biological property, possibly due to its antioxidant, antiviral, and cation channel modulator properties (Parnas et al. 2009; Chen et al. 2015; Naeem et al. 2021). Hence its protective action against the Covid-19 was recently reported (Javed et al. 2021). Some members of TRP superfamily are differently affected in the hippocampal neurons by the treatment of CARV (Parnas et al. 2009). The TRPA1 and TRPV3 channels are activated by CARV (Parnas et al. 2009; Jeong et al. 2020). TRPM7 is activated in neurons by several stimuli, including oxidative stress, although it is inhibited by the treatment of CARV (Lipski et al. 2006; Jeong et al. 2020). Hence, the TRPM 2 and TRPV4 channels may be modulated in neuronal cell lines by the treatment of CARV.

In the current study, I postulated that CARV was the ability to abolish oxidative stress-mediated TRPM7 activations. The present study aimed to elucidate the antagonist action of CARV on the activation of TRPM2 and TRPV4 in the neuronal cell and kidney lines. By the results of current study, I aimed to discover a specific and naturel channel blocker for treating the TRPM2 and TRPV4 activation-induced neuronal diseases.

\section{Materials and methods}

\section{Cell culture}

The presence of naturel TRPM2 and TRPV4 channels was reported in the SH-SY5 by the Western blot analyses (Bollimuntha et al. 2005; Bao et al. 2016; Akyuva and Nazıroğlu 2020; Sánchez et al. 2020). The result of a recent study was also indicated the presence of TRPM2 channel in the BV-2 microglial cells (Sha'fie et al. 2020). In the current study, I used SH-SY5Y and BV-2 cells (ATCC, LGC Standards GmbH, Wesel, Germany). There are no naturel TRPM2 and TRPV4 expressions in HEK293. Hence, I also used HEK293 cells (ATCC) as models of TRPM2 and TRPV4 gene knockout cells. The SH-SY5Y cells were cultured in a DMEM-LPA and medium Ham's F-12 (HAM-12-A) with low glucose 
(Capricorn Sci. GmbH, Ebsdorfergrund, Germany) as described in previous studies (Akyuva and Nazıroğlu 2020; Armağan and Nazıroğlu 2021). BV-2 and HEK293 cells were cultured in the DMEM medium with low glucose (Capricorn). Both medium mixtures were additionally supplemented with fetal bovine serum (10\%) and antibiotic mixture (penicillin/streptomycin) (1\%) (Biochrom Ltd. Cambridge, United Kingdom). The cells were cultured in a humidified atmosphere $\left(5 \% \mathrm{CO}_{2}\right.$ and $\left.37^{\circ} \mathrm{C}\right)(\mathrm{NB}-203 \mathrm{QS}$, Gyeonggi-do, Korea) at a density of $1 \times 10^{6}$ cells per T 25 flask.

\section{Transfection of HEK293 cells with TRPM2 and TRPV4}

HEK293 cells were transfected with $4 \mu \mathrm{g}$ plasmid or cDNAs of human TRPM2 and TRPV4 (gifts from Dr. Simon Hebeisen, B'SYS GmbH, Basel, Switzerland) from each construct and Lipofectamine 2000 (6 $\mu \mathrm{l})$ in Opti-MEM reduced serum medium $(400 \mu \mathrm{l})$ in dishes with bottom glass. The transfected cells (HEK293 ${ }^{\mathrm{M} 2}$ and HEK293 ${ }^{\mathrm{V} 4}$ ) were controlled in the fluorescein microscope (Axiover 40, Zeiss, Ankara, Turkey) by using a GFPexpressing TRPM2 and TRPV4. Functional studies were performed $18 \mathrm{~h}$ post-transfection.

\section{Study groups}

The SH-SY5Y, BV-2, HEK293, HEK293 ${ }^{\mathrm{M} 2}$, and HEK $293^{\mathrm{V}}$ cells were divided into five main groups as follows:

Control (Cntr) cells were kept in the same cell culture medium and conditions for $24 \mathrm{~h}$ without treatments.

The cells in the group of $\mathrm{H}_{2} \mathrm{O}_{2}$ were incubated with $\mathrm{H}_{2} \mathrm{O}_{2}$ $(1 \mathrm{mM}$ ) for $1 \mathrm{~h}$ (Akyuva and Nazıroğlu 2020; Armağan and Nazıroğlu 2021).

The cells in the group of GSK were incubated with GSK $(100 \mathrm{nM})$ for $1 \mathrm{~h}$ (Nakagawa et al. 2020).

The cells in the group of $\mathrm{H}_{2} \mathrm{O}_{2}+\mathrm{CARV}$ were treated with $\mathrm{H}_{2} \mathrm{O}_{2}(1 \mathrm{mM})$ for $1 \mathrm{~h}$, and then they were further incubated with CARV $(100 \mu \mathrm{M})$ for 1 or $24 \mathrm{~h}$. The nontoxic dose and incubation time of CARV were found in the cells by using the cell viability test.

The cells in the group of GSK+CARV were treated with GSK (100 $\mathrm{nM})$ for $1 \mathrm{~h}$ and then they were further incubated with CARV $(100 \mu \mathrm{M})$ for 1 or $24 \mathrm{~h}$.

In some experiments, the cells in the group of $\mathrm{H}_{2} \mathrm{O}_{2}+\mathrm{ACA} / 2-\mathrm{APB}$ and GSK+RuRe were treated with $\mathrm{H}_{2} \mathrm{O}_{2}(1 \mathrm{mM})$ and GSK $(100 \mathrm{nM})$ for $1 \mathrm{~h}$ and then they were further incubated with ACA $(25 \mu \mathrm{M}) / 2$-APB $(100 \mu \mathrm{M})$ or
RuRe $(1 \mu \mathrm{M})$ for 5-25 min (Akyuva and Nazıroğlu 2020; Nakagawa et al. 2020; Armağan and Nazıroğlu 2021).

\section{Laser scan confocal microscope (LSM-800) analyses in the SH-SY5Y, BV-2, HEK293, HEK293 ${ }^{\mathrm{M} 2}$, and HEK293 ${ }^{\mathrm{V} 4}$ cells}

I assayed TRPM2 and TRPV4 activation-mediated fluorescence intensity changes of $\mathrm{cCa}^{2+}$ in the SH-SY5Y, BV-2, HEK293, HEK293 ${ }^{\mathrm{M} 2}$, and HEK293 ${ }^{\mathrm{V} 4}$ cells in the laser scan confocal microscope (LSM800) (Zeiss, Ankara, Turkey) by using $1 \mu \mathrm{M}$ Fluo 3-AM incubation previously described (Akyuva and Nazıroğlu 2020; Armağan and Nazıroğlu 2021).

The Hoechst is a permeable dye into the nucleus of living cell, and then it indicates blue color in the cell image. However, the propidium iodide (PI) stains the nucleus of death cells with red color. The SH-SY5Y in the dishes with glass bottom was incubated with the combination of PI $(2 \mu \mathrm{g} /$ $\mathrm{ml})$ and Hoechst $33342(5 \mu \mathrm{M})$ before the LSM800 analyses (Akyuva and Nazıroğlu 2020; Armağan and Nazıroğlu 2021).

The influx of JC-1 probe increases into the mitochondrial membranes according to the increase of mitochondrial membrane potential $(\Delta \Psi \mathrm{m})$ level. The increase of $\Delta \Psi \mathrm{m}$ in the mitochondria were assayed by the incubation of $2 \mu \mathrm{M} \mathrm{JC}-1$ stain (Akyuva and Nazıroğlu 2020; Armağan and Nazıroğlu 2021).

The generation of cROS was analyzed in the LSM800 microscope by using the $2^{\prime}, 7^{\prime}$-dichlorofluorescin diacetate (DCFH-DA) non-fluorescent stain. The DCFH-DA is converted to a fluorescent intracellular stain (2', 7' -dichlorofluorescein, DCF) in the cytosol of cells by the generation of cellular oxidative stress. The SH-SY5Y cells were incubated in the presence of $4 \mu \mathrm{M}$ DCFH-DA (Akyuva and Nazıroğlu 2020; Armağan and Nazıroğlu 2021).

A cell permeable red fluorescent probe of mitochondria is MitoTracker Red CM-H2Xros. The generation of mROS in the mitochondria was imaged in the microscope of LSM800 by using $150 \mathrm{nM}$ MitoTracker Red CM-H2Xros fluorescent stain, according to the manufacturer's instructions (Akyuva and Nazıroğlu 2020; Armağan and Nazıroğlu 2021).

The Fluo 3-AM was purchased from Calbiochem $\mathrm{GmbH}$ (Darmstadt, Germany). The stains of Hoechst 33,342, PI, and DCFH-DA were purchased from Cell Signaling Technologies (Danvers, Massachusetts, USA). The stain of JC-1 was purchased from Cayman Chemical Inc. (Ann Arbor, Michigan, USA). The SH-SY5Y, BV-2, and HEK293 cells were incubated with the stains for $60 \mathrm{~min}$ at $37{ }^{\circ} \mathrm{C}$ and $5 \% \mathrm{CO}_{2}$ in dark conditions (Akyuva and Nazıroğlu 2020; Armağan and Nazıroğlu 2021). Then, the stains were removed from the media by washing (1xPBs). The fluorescence intensities of cells were measured in the microscope of 
LSM800 by using the ZEN program (Zeiss), and they were indicated by the units of arbitrary (a.u.). The death cells were counted in the images of PI/Hoechst by using the Image $\mathbf{J}$ program. The rate (PI/Hoechst) of cell death was indicated as percentage changes.

\section{Electrophysiology}

The patch-clamp electrophysiology records in the SH-SY5Y and HEK293 cells were taken by using an EPC10 patchclamp set (HEKA GmbH, Lamprecht, Germany). The holding potential and pipette resistance were kept as $-60 \mathrm{mV}$ and $4 \pm 3 \mathrm{M} \Omega$, respectively. The standard pipette (cytosolic) and patch chamber (extracellular) buffers were used, and their content details were given in the previous studies (Butenko et al. 2012; Akyuva and Nazıroğlu 2020; Armağan and Nazıroğlu 2021). For preparing $\mathrm{Na}^{+}$free solution, I used $\mathrm{N}$-methyl-D-glucamine $\left(\mathrm{NMDG}^{+}\right)$instead of $\mathrm{Na}^{+}$. The TRPM2 is activated in the presence of cytosolic solution with high $\mathrm{Ca}^{2+}(1 \mu \mathrm{M})$ (McHugh et al. 2003). Hence, the cytosolic solution with high $\mathrm{Ca}^{2+}(1 \mu \mathrm{M})$ instead of normal $\mathrm{Ca}^{2+}(0.1 \mu \mathrm{M})$ was used in the TRPM2 patch-clamp experiments. In the TRPM2 patch-clamp records, the channel was stimulated by intracellular (via patch pipette) ADPR (1 $\mu \mathrm{M})$, although it was inhibited by extracellular ACA $(25 \mu \mathrm{M})$ and CARV (50 and $100 \mu \mathrm{M}$ ) (Akyuva and Nazıroğlu 2020; Armağan and Nazıroğlu 2021). In the TRPV4 patch-clamp records, the channel was stimulated by extracellular GSK, although it was inhibited by RuRe $(1 \mu \mathrm{M})$ and CARV (100 $\mu M)$ (Parnas et al. 2009; Nakagawa et al. 2020). The results of TRPM2 and TRPV4 current densities were shown as pA/ $\mathrm{pF}$ [the maximal current amplitudes (pA)/cell capacitance $(\mathrm{pF})]$.

\section{The assay of cell viability}

The number, debris amount, and viability percentage of SHSY5Y cells were assayed in the CASY Cell Counter + Analyzer System Model TT electronic system by using CASY tone solution (Roche Innovatis AG, Routlingen, Germany). The analyses are performed by using an electronic probe.

\section{The assays of CASP-3, CASP-9, and apoptosis}

Cleavages of fluorogenic substrates (N-acetyl-Asp-Glu-ValAsp-7-amido-4-methylcoumarin-Ac-DEVD-AMC for CASP -3) and N-acetyl-Leu-Glu- His-Asp-7-amino-4-methylcoumarin-Ac-LEHD-AMC for CASP -9) (Bachem AG, Bubendorf, Switzerland) were used for the caspase assays. For the caspase assays, the SH-SY5Y cells were incubated with substrate solutions $\left(0.2 \mathrm{ml}\right.$ each) for $1 \mathrm{~h}$ at $37^{\circ} \mathrm{C}$ (Akyuva and Nazıroğlu 2020; Armağan and Nazıroğlu 2021). The substrate cleavages were used to continuously measure the activity of CASP -3 and CASP -9 in the cell extracts, using an automatic microplate reader (Infinite 200 PRO, Tecan $\mathrm{GmbH}$, Männedorf, Switzerland) (Excitation: of $360 \mathrm{~nm}$. Emission: $460 \mathrm{~nm}$ ).

For the apoptosis assay, I used a commercial kit (Biocolor Ltd. Northern Ireland) as described previously (Akyuva and Nazıroğlu 2020; Armağan and Nazıroğlu 2021). The apoptosis analyses were performed in the Infinite 200 PRO by using according to the manufacturer's description.

The results of CASP -3, CASP -9, and apoptosis levels are expressed as \% of control.

\section{The measurements of lipid peroxidation (MDA), reduced glutathione (GSH), and GSH peroxidase (GSHPx)}

The absorbance changes of total protein, MDA, GSH and GSHPx levels in the SH-SY5Y cells were assayed by using a spectrophotometer (Cary 60 UV-Vis, Agilent, Santa Clara, CA, USA) as described in the previous studies (Akyuva and Nazıroğlu 2020; Armağan and Nazıroğlu 2021). The unit of $\mu \mathrm{mol}$ per $\mathrm{g}$ protein was used for expressions of MDA and GSH concentrations in the cells, while the unit of IU per $g$ protein was used for expressing the GSHPx activity.

\section{Statistical analyses}

The presence of statistical significance in the data was detected by using the ANOVA program (SPSS). The level of statistical significance was detected in the data by using the Kruskal-Wallis analysis. All data are reported as mean values \pm standard deviation (STD). A $p \leq 0.05$ value was accepted as indicative of statistical significance.

\section{Results}

\section{The $\mathrm{H}_{2} \mathrm{O}_{2}$ and GSK-mediated increases of $\mathrm{Ca}^{2+}$ fluorescence intensity via the activations of TRPM2 and TRPV4 in the SH-SY5Y neuronal and BV-2 microglia cells were diminished by the CARV}

As the first step in the present study whether the inhibitions of TRPM2 and TRPV4 are related to the treatments of CARV, the influences of the channels on the changes of $\mathrm{CCa}^{2+}$ concentration was investigated by determination of $\mathrm{CCa}^{2+}$ concentration, using the TRPM2 $\left(\mathrm{H}_{2} \mathrm{O}_{2}\right)$ and TRPV4 (GSK) agonists. In the image (Fig. 1a and Suppl. Fig. 1a), line (Fig. 1b and Suppl. Fig. 1b), and column (Fig. 1c and Suppl. Fig. 1c) results of the Cntr, $\mathrm{H}_{2} \mathrm{O}_{2}$, and $\mathrm{H}_{2} \mathrm{O}_{2}+\mathrm{CARV}$, the fluorescence intensities of $\mathrm{cCa}^{2+}$ concentration in the SH-SY5Y and BV-2 cells were increased in the groups of $\mathrm{H}_{2} \mathrm{O}_{2}$ by TRPM2 activation ( $\mathrm{p} \leq 0.05$ ). The fluorescence 

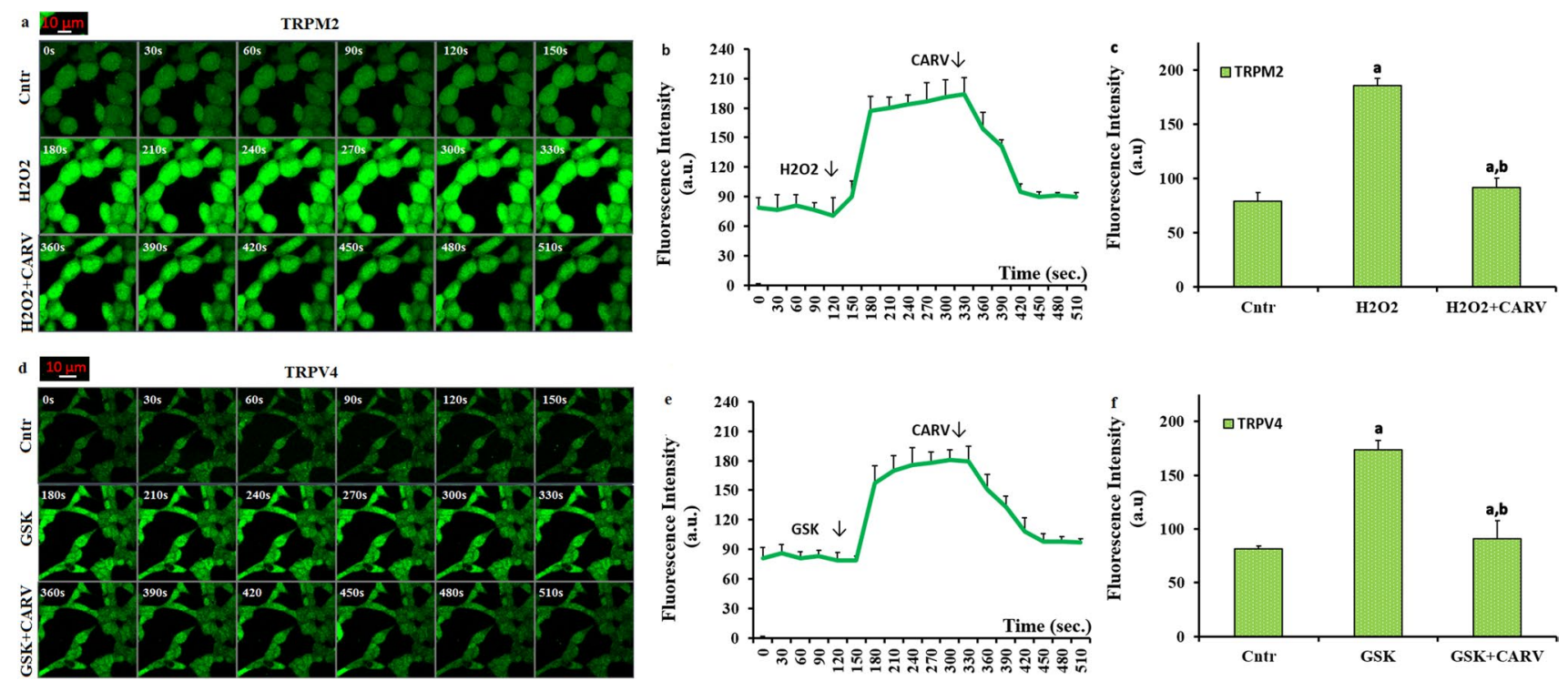

Fig. 1 The treatment of carvacrol (CARV) diminished $\mathrm{H}_{2} \mathrm{O}_{2}$ and GSK-mediated increase of $\mathrm{cCa}^{2+}$ concentration via inhibition of TRPM2 and TRPV4 in the SH-SY5Y cells. (Mean \pm STD). The SHSY5Y cells in the dishes of control (Cntr), $\mathrm{H}_{2} \mathrm{O}_{2}, \mathrm{GSK}, \mathrm{H}_{2} \mathrm{O}_{2}+\mathrm{CARV}$, and GSK+CARV groups were stained with the dye of Fluo 3-AM $(1 \mu \mathrm{M}$ for $60 \mathrm{~min})$. After washing the cells, they were stimulated by $\mathrm{H}_{2} \mathrm{O}_{2}(1 \mathrm{mM})$ or GSK $(100 \mathrm{nM})$, although they were inhibited by CARV $(100 \mu \mathrm{M})$. The representative images groups on the increase of $\mathrm{cCa}^{2+}$ concentration through TRPM2 inhibition in the Cntr, $\mathrm{H}_{2} \mathrm{O}_{2}$, and $\mathrm{H}_{2} \mathrm{O}_{2}+\mathrm{CARV}$ in the confocal microscope with $40 \mathrm{x}$ oil objective were shown a, although the representative images on the $\mathrm{cCa}^{2+}$

intensity of $\mathrm{cCa}^{2+}$ was reduced in the group of $\mathrm{H}_{2} \mathrm{O}_{2}+\mathrm{CARV}$ as compared to $\mathrm{H}_{2} \mathrm{O}_{2}$ only ( $\mathrm{p} \leq 0.05$ ) (Fig. 1c and Suppl. Fig. 1c). In the image (Fig. 1d), line (Fig. 1e), and column (Fig. 1f) results of the Cntr, GSK, and GSK+CARV, the fluorescence intensity of $\mathrm{cCa}^{2+}$ was increased in the groups of GSK by TRPV4 activation ( $\mathrm{p} \leq 0.05)$. However, its concentration was decreased in the group of GSK+CARV as compared to GSK only $(\mathrm{p} \leq 0.05)$. The results were also confirmed by the time-dependent records of the images (Fig. 1b, Suppl. Fig. 1b, and e). The results are clearly indicated the protective role of CARV on the activations of TRPM2 and TRPV4-mediated $\mathrm{Ca}^{2+}$ influx in the SH-SY5Y cells.

\section{There were no actions of $\mathrm{H}_{2} \mathrm{O}_{2}$ and GSK on the activations of TRPM 2 and TRPV4 in the absence of extracellular $\mathrm{Ca}^{2+}\left(\mathrm{NoCa}^{2+}\right)$ or the preincubations with CARV (24 h) and PARP-1 inhibitors in the SH-SY5Y cells}

Accumulating evidence indicates that the increase of $\mathrm{cCa}^{2+}$ concentration in the SH-SY5Y is promoted by several stimuli, including the treatments of $\mathrm{H}_{2} \mathrm{O}_{2}$ and GSK (Bollimuntha et al. 2005; Bao et al. 2016; Akyuva and Nazıroğlu 2020; Sha'fie et al. 2020; Armağan and Nazıroğlu 2021). concentration through TRPV4 inhibition in the groups of Cntr, GSK, and GSK+CARV groups in the LSCM-800 microscopee with 40x oil objective were shown $\mathbf{d}$. The line (1b) and column (1c) mean fluorescence intensities of the Fluo 3-AM (150 s) are shown in the groups of Cntr, $\mathrm{H}_{2} \mathrm{O}_{2}$, and $\mathrm{H}_{2} \mathrm{O}_{2}+\mathrm{CARV}$ in the $\mathbf{b}$ and $\mathbf{c}$, although the line (1e) and column (1f) mean fluorescence intensities of the Fluo 3-AM (150 s) are shown in the groups of Cntr, GSK, and GSK+CARV are shown in the e and f. The scale bar was kept as $10 \mu \mathrm{m}$. One example image of each figure was selected from 25-30 SH-SY5Y of 6 independent experiments for each condition ( ${ }^{\mathrm{a}} \mathrm{p} \leq 0.05$ vs. Cntr. ${ }^{\mathrm{b}} \mathrm{p} \leq 0.05$ vs. $\mathrm{H}_{2} \mathrm{O}_{2}$ or GSK group)

This increase results from the influx of extracellular $\mathrm{Ca}^{2+}$ (Butenko et al. 2012). The influx of extracellular $\mathrm{Ca}^{2+}$ was induced by several TRP channels, including TRPM2 and TRPV4. In the absence of extracellular $\mathrm{Ca}^{2+}\left(\mathrm{NoCa}^{2+}\right)$, the absence of TRPM 2 and TRPV4 activations was reported in the HEK293 and pancreatic beta cells (McHugh et al. 2003; Skrzypski et al. 2003; Shi et al. 2004). Hence, the activations of TRPM 2 and TRPV4 are affected by the absence of extracellular $\mathrm{Ca}^{2+}\left(\mathrm{NoCa}^{2+}\right)$. As the second step in the current study, I tested whether the $\mathrm{H}_{2} \mathrm{O}_{2}$ and GSK-induced increases of $\mathrm{cCa}^{2+}$ concentrations are related with the influx of extracellular $\mathrm{Ca}^{2+}$ (through the activations of TRPM2 and TRPV4). For the aim, I performed an extracellular buffer experiment without $\mathrm{Ca}^{2+}\left(\mathrm{NoCa}^{2+}\right)$ in the SH-SY5Y cells. In addition, I tested preincubation ( $24 \mathrm{~h}$ ) of CARV on the GSK or $\mathrm{H}_{2} \mathrm{O}_{2}$-mediated $\mathrm{Ca}^{2+}$ influx via the activation of TRPM2 and TRPV4 in the SH-SY5Y cells. The SH-SY5Y cells in the groups of $\mathrm{NoCa}^{2+}$ and CARV $(24 \mathrm{~h})$ were incubated in the $\mathrm{Ca}^{2+}$ free extracellular buffer with Fluo 3-AM for $60 \mathrm{~min}$. The $\mathrm{H}_{2} \mathrm{O}_{2}$ and GSK were also prepared in the $\mathrm{NoCa}^{2+}$ extracellular buffer. In the results of images (Fig. 2a and f) and column (Fig. 2b, c, f and g), I observed no change of $\mathrm{cCa}^{2+}$ concentration in the $\mathrm{NoCa}^{2+}$ and CARV (24 h) groups of SH-SY5Y cells after the stimulations of $\mathrm{H}_{2} \mathrm{O}_{2}$ 

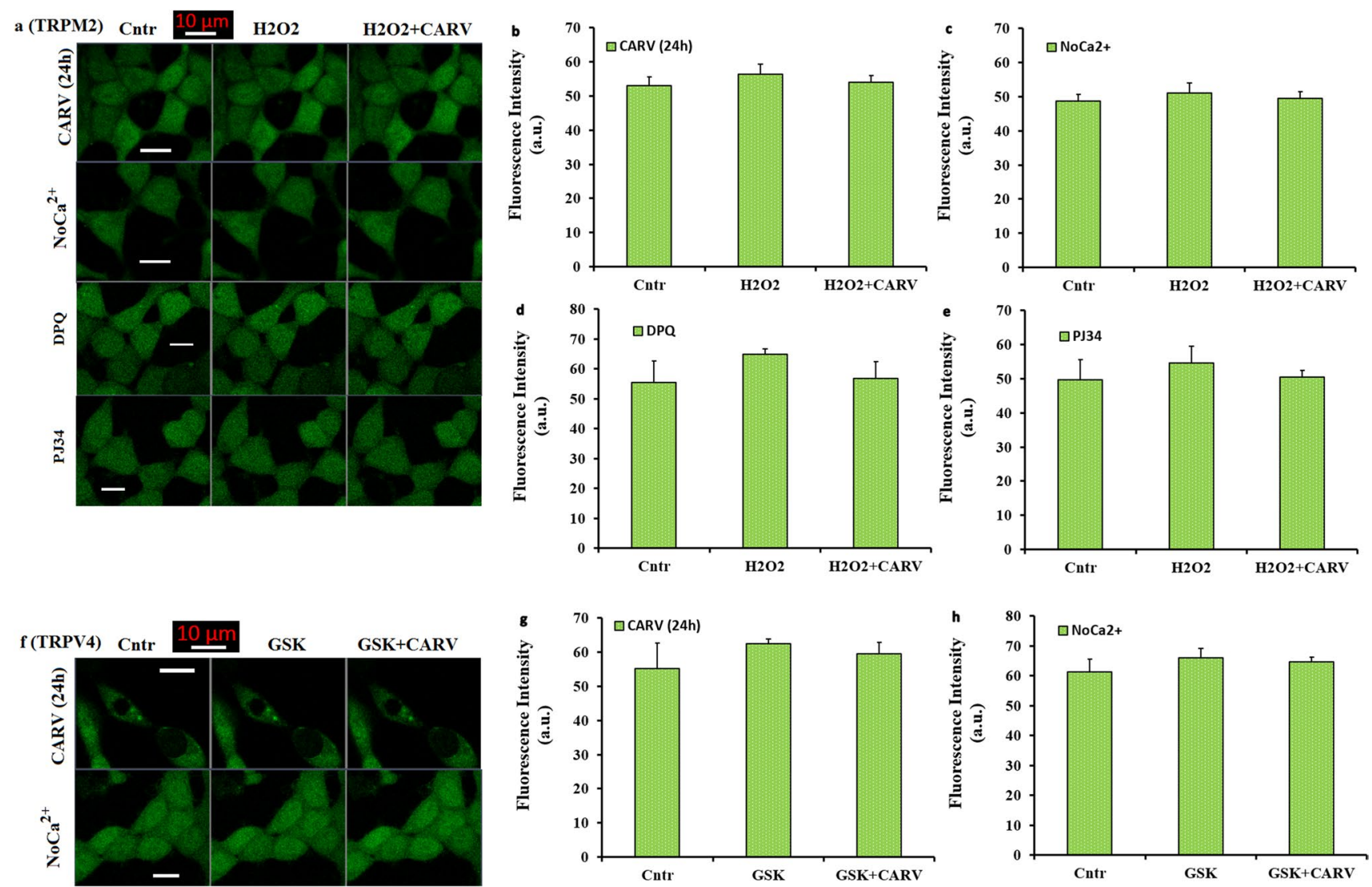

Fig. 2 There were no effects of $\mathrm{H}_{2} \mathrm{O}_{2}$ and GSK on the TRPM2 and TRPV4 activation in the absence of extracellular $\mathrm{Ca}^{2+}\left(\mathrm{NoCa}^{2+}\right)$ and the treatments of CARV (24h) and PARP-1 inhibitors in the SHSY5Y cells. (Mean \pm STD). The SH-SY5Y cells in the CARV (24h), $\mathrm{NoCa}^{2+}$, DPQ (30 $\mu \mathrm{M}$ for $\left.30 \mathrm{~min}\right)$ and PJ34 (1 $\mu \mathrm{M}$ for $\left.30 \mathrm{~min}\right)$ groups were stained with Fluo 3-AM $(1 \mu \mathrm{M}$ for $60 \mathrm{~min})$. After washing the cells, the stained cells were stimulated by $\mathrm{H}_{2} \mathrm{O}_{2}(1 \mathrm{mM})$ or $\mathrm{GSK}(100$ $\mathrm{nM}$ ). Representative LSCM-800 (objective: $40 \mathrm{x}$ oil) images and mean

and GSK or the treatment of CARV ( $\mathrm{p} \geq 0.05)$. The results indicated the involvement of extracellular $\mathrm{Ca}^{2+}$ influx and CARV preincubation ( $24 \mathrm{~h}$ ) on the $\mathrm{H}_{2} \mathrm{O}_{2}$ and GSK-induced $\mathrm{cCa}^{2+}$ concentration increase in the SH-SY5Y cells.

The activation of ADP-ribosyl cyclase in the cell membrane receptor (CD38) catalysis the nicotinamide adenine dinucleotide $\left(\mathrm{NAD}^{+}\right)$(Guse 2015). From NAD ${ }^{+}$, ADPR is synthetized in the nucleus of cells by the activation of PARP-1 enzyme (Nazıroğlu 2007). The ADPR induces $\mathrm{Ca}^{2+}$ influx from the extracellular sources via the activation of TRPM2 (Fonfria et al. 2004; Nazıroğlu and Lückhoff 2008). Hence, the TRPM2 channel is activated in the SH-SY5Y cells by the PARP-1 activation-induced intracellular ADPR (Fonfria et al. 2004; Nazıroğlu and Lückhoff 2008; Bao et al. 2016; Malko et al. 2021). The generation of ADPR in the SH-SY5Y could be decreased by the inhibitors of PARP-1 (Butenko et al. 2012; Akyuva and Nazıroğlu 2020). The DPQ and PJ34 are two well-known PARP1 inhibitors in colon values of Cntr, $\mathrm{H}_{2} \mathrm{O}_{2}$, and $\mathrm{H}_{2} \mathrm{O}_{2}+\mathrm{CARV}$ groups on the $\mathrm{cCa}^{2+}$ concentration through TRPM2 in the CARV (a and b), $\mathrm{NoCa}^{2+}(\mathbf{a}$ and $\mathbf{c}$ ), DPQ (a and d), and PJ34 (a and e) groups were shown in the Fig. 2. Effects of CARV treatments on the GSK-induced changes of $\mathrm{cCa}^{2+}$ intensity in the CARV (f and $\mathbf{g}$ ) and $\mathrm{NoCa}^{2+}(\mathbf{f}$ and $\mathbf{h})$ groups were also shown by images (Fig. 2f) and columns (Figs. 2g and h). The scale bar: $10 \mu \mathrm{m}$

the TRPM2 channel experiments (Armağan and Nazıroğlu 2021; Özkaya et al. 2021). Hence, I wanted to test modulator actions of ADPR production through DPQ and PJ34 treatment on the $\mathrm{cCa}^{2+}$ concentrations in the SH-SY5Y cells. The cells were pretreated with PJ34 $(1 \mu \mathrm{M})$ or DPQ $(30 \mu \mathrm{M})$ for $30 \mathrm{~min}$. There was no increase in the Fluo 3-AM florescence intensity in the groups of PJ34 (Fig. 2d) and DPQ (Fig. 2e). The results of PARP-1 inhibition confirmed the involvement of TRPM 2 channel activity on the $\mathrm{cCa}^{2+}$ concentration in the SH-SY5Y cells.

\section{There was no action of $\mathrm{H}_{2} \mathbf{O}_{2}$ or GSK on the increases of $\mathrm{CCa}^{2+}$ concentration in the absence of TRPM2 and TRPV4 in the HEK293 cells}

Accumulating evidence indicates that there is no naturel TRPM2 and TRPV4 channels in the HEK293 cells (McHugh et al. 2003; Shi et al. 2004; Du et al. 2012). 

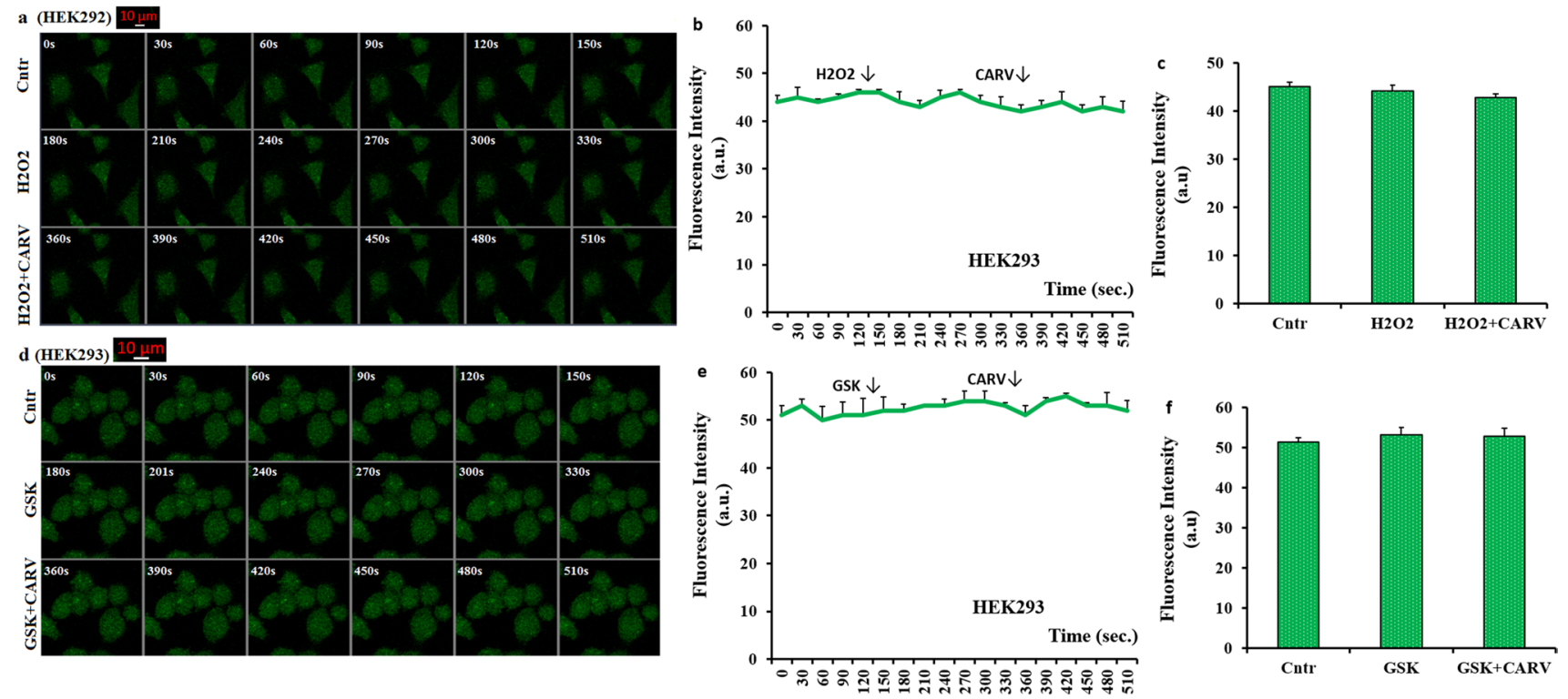

Fig. 3 There was no effect of CARV on the increase of $\mathrm{cCa}^{2+}$ concentration in the absence of TRPM2 and TRPV4 in the HEK293 cells. (Mean \pm STD). The HEK293 cells in the groups of control (Cntr), $\mathrm{H}_{2} \mathrm{O}_{2}$, GSK, $\mathrm{H}_{2} \mathrm{O}_{2}+\mathrm{CARV}$, and $\mathrm{GSK}+\mathrm{CARV}$ were stained with Fluo 3-AM ( $1 \mu \mathrm{M}$ for $60 \mathrm{~min})$. After washing the cells, the cells were stimulated by by $\mathrm{H}_{2} \mathrm{O}_{2}(1 \mathrm{mM})$ or GSK $(100 \mathrm{nM})$, although they were inhibited by CARV $(100 \mu \mathrm{M})$. The representative confocal microscope (objective: 40x oil) images, mean colon, and line values on the changes of $\mathrm{cCa}^{2+}$ concentration via the activation of TRPM2 in the HEK293 in the groups of Cntr, $\mathrm{H}_{2} \mathrm{O}_{2}$, and $\mathrm{H}_{2} \mathrm{O}_{2}+\mathrm{CARV}$ groups were shown in the $\mathbf{a}, \mathbf{b}$, and $\mathbf{c}$, respectively. Effects of CARV treatments on the GSK-induced changes of $\mathrm{cCa}^{2+}$ concentration intensity in the HEK293 were also shown by images (d), lines (e), and columns (f). The scale bar: $10 \mu \mathrm{m}$. One example image of each figure was selected from 20-25 HEK293 of 6 independent experiments for each condition
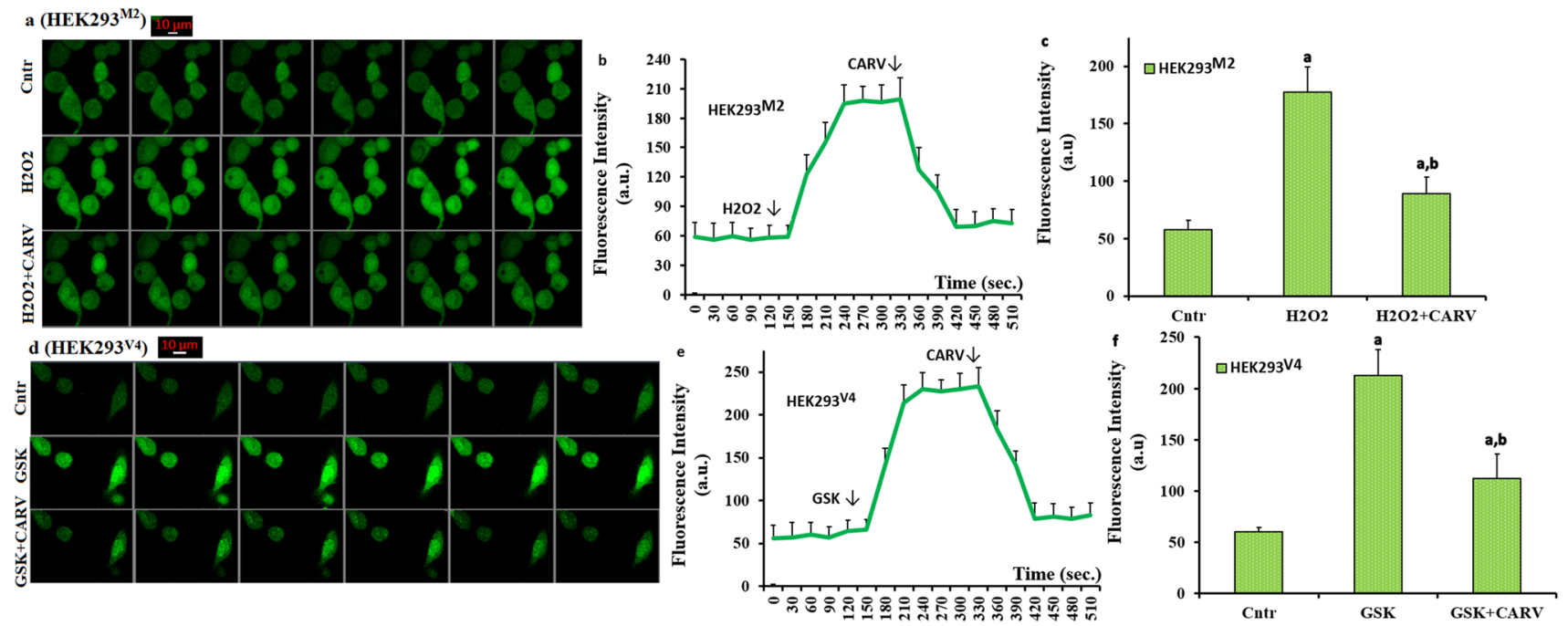

Fig. 4 The treatment of CARV modulated the increase of $\mathrm{cCa}^{2+}$ concentration via inhibition of TRPM2 and TRPV4 in the HEK293 ${ }^{\mathrm{M} 2}$ and HEK $293^{\mathrm{V} 4}$ cells. (Mean \pm STD). The HEK $293^{\mathrm{M} 2}$ and HEK293 ${ }^{\mathrm{V} 4}$ cells in the in the control (Cntr), $\mathrm{H}_{2} \mathrm{O}_{2}, \mathrm{GSK}, \mathrm{H}_{2} \mathrm{O}_{2}+\mathrm{CARV}$, and GSK+CARV groups were stained with Fluo 3-AM $(1 \mu \mathrm{M}$ for $60 \mathrm{~min})$. After washing the cells, the stained cells were stimulated by by $\mathrm{H}_{2} \mathrm{O}_{2}(1 \mathrm{mM})$ or GSK $(100 \mathrm{nM})$, although they were inhibited by CARV $(100 \mu \mathrm{M})$. Representative confocal microscope (objec- tive: 40x oil) images, mean colon and line values of $\mathrm{Cntr}, \mathrm{H}_{2} \mathrm{O}_{2}$, and $\mathrm{H}_{2} \mathrm{O}_{2}+$ CARV groups on the $\mathrm{cCa}^{2+}$ concentration through TRPM2 in the HEK $293^{\mathrm{M} 2}$ were shown $\mathbf{a}, \mathbf{b}$, and $\mathbf{c}$, respectively. Effects of CARV treatments on the GSK-induced changes of $\mathrm{cCa}^{2+}$ intensity in the HEK $293^{\mathrm{V} 4}$ were also shown by images (d), lines (e), and columns (f). The scale bar: $10 \mu \mathrm{m}$. One example image of each figure was selected from 20-25 HEK293 of 6 independent experiments for each condition 

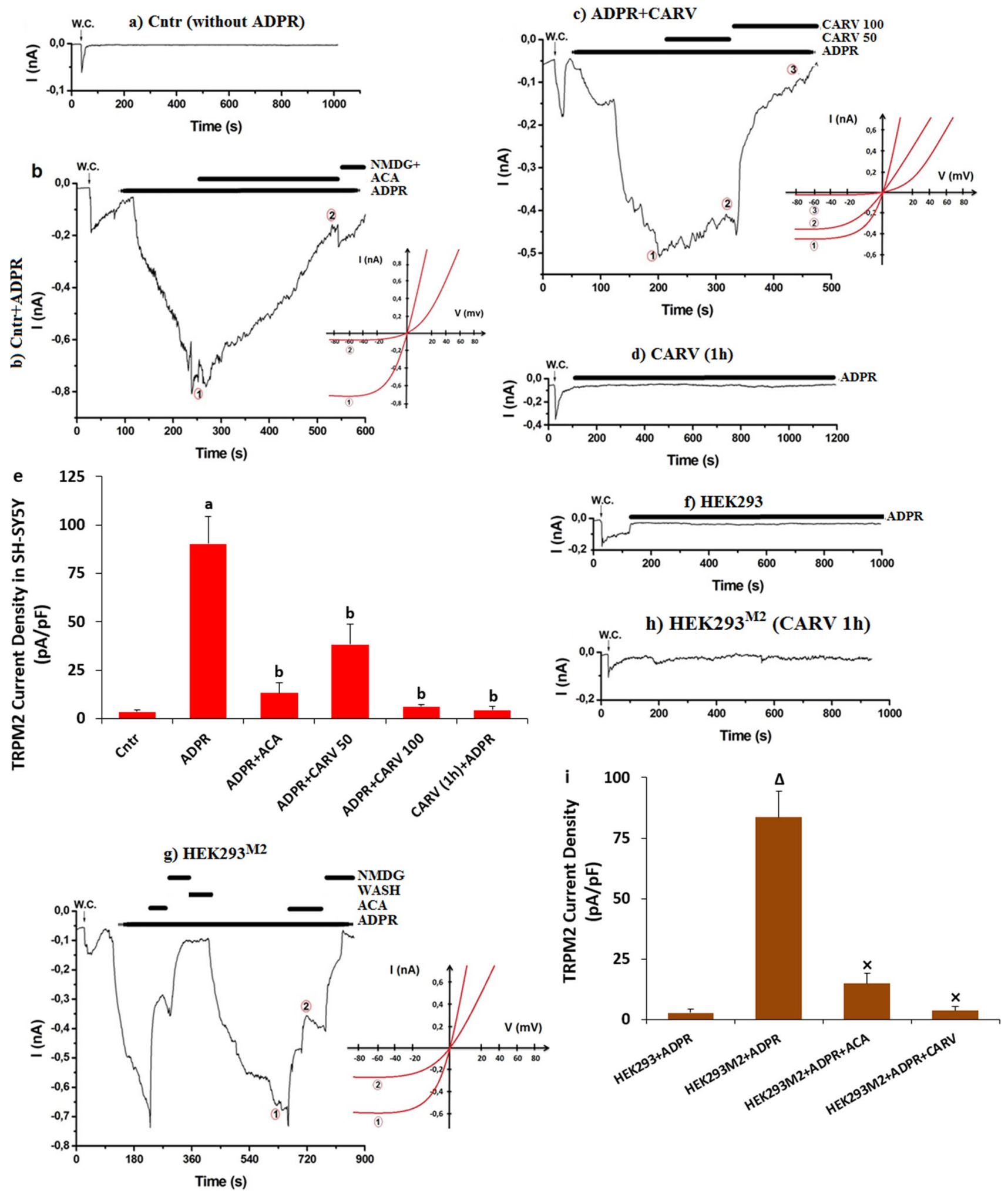

observed in the cells (McHugh et al. 2003; Shi et al. 2004; Du et al. 2012). As the third step in the current study, I tested the effects of TRPM2 $\left(\mathrm{H}_{2} \mathrm{O}_{2}\right)$ and TRPV4 (GSK) agonists on the increase of $\mathrm{cCa}^{2+}$ concentration in the absence of TRPM2 (HEK293 cells) or the presence of TRPM2 (HEK293 ${ }^{\mathrm{M} 2}$ ) and TRPV4 (HEK293 ${ }^{\mathrm{V} 4}$ ). The HEK293, HEK293 ${ }^{\mathrm{M} 2}$, and HEK293 ${ }^{\mathrm{V} 4}$ cells were incubated in the $\mathrm{Ca}^{2+}$ buffer with Fluo 3-AM for $60 \mathrm{~min}$. The 
4Fig. 5 ADPR induced increase of TRPM2 current densities (pA/ $\mathrm{pF}$ ) in the SH-SY5Y cells but not in the HEK293 cells. The ADPRinduced increase of TRPM2 current density was diminished in the SH-SY5Y cells by the treatment of CARV. (Mean \pm STD and $n=4-$ 6). The TRPM 2 currents in the SH-SY5Y cells were induced by the stimulation of cytosolic ADPR $(1 \mathrm{mM})$, but they were blocked by CARV (50 and $100 \mu \mathrm{M}$ ). W.C.: The record of whole cell. (a) Cntr (without ADPR). (b) Cntr (with ADPR and ACA). (c) ADPR+CARV $(50$ and $100 \mu \mathrm{M})$. (d) CARV (1 h)+ADPR. e. Mean currents densities of TRPM2 in the SH-SY5Y cells. f. HEK293 cells + ADPR (without TRPM2). g. HEK293 ${ }^{\mathrm{M} 2}$ cells + ADPR (with TRPM2). h. HEK293 ${ }^{\mathrm{M} 2}$ cells + CARV (1 h) + ADPR (with TRPM2). i. Mean currents densities of HEK293 and HEK293 ${ }^{\mathrm{M} 2}$ after the treatments of ADPR, ACA, and CARV ( ${ }^{\mathrm{a}} \mathrm{p} \leq 0.05$ vs. Cntr. ${ }^{\mathrm{b}} \mathrm{p} \leq 0.05$ vs. Cntr+ADPR group. ${ }^{\Delta_{\mathrm{p}}}$ $\leq 0.05$ vs. HEK $293+$ ADPR group. ${ }^{x} \leq 0.05$ vs. HEK $293^{\mathrm{M} 2}+$ ADPR group)

agonists and CARV were also prepared in the extracellular buffer with $\mathrm{Ca}^{2+}$. In the results of images (Fig. 3a and d), line (Fig. 3b and e), and column (Fig. 3c and f), I observed no change of $\mathrm{cCa}^{2+}$ concentration in the $\mathrm{Cntr}, \mathrm{H}_{2} \mathrm{O}_{2}$, GSK, $\mathrm{H}_{2} \mathrm{O}_{2}+\mathrm{CARV}$, and GSK+CARV groups in HEK293 cells after the stimulations of GSK and $\mathrm{H}_{2} \mathrm{O}_{2}$ or the treatment of CARV ( $\mathrm{p} \geq 0.05)$.

I repeated the analyses of images (Fig. 4a and d), line (Fig. 4b and e), and columns (Fig. 4c and f) in the HEK293 ${ }^{\mathrm{M} 2}$ (TRPM2 transfected) and HEK293 ${ }^{\mathrm{V} 4}$ (TRPV4 transfected) cells. The levels of $\mathrm{cCa}^{2+}$ were markedly ( $\mathrm{p} \leq$ 0.05 ) increased in the HEK $293^{\mathrm{M} 2}$ and HEK $293^{\mathrm{V} 4}$ cells by the stimulations of $\mathrm{H}_{2} \mathrm{O}_{2}$ and GSK, although their levels were significantly $(\mathrm{p} \leq 0.05)$ decreased in the $\mathrm{H}_{2} \mathrm{O}_{2}+\mathrm{CARV}$ and GSK+CARV groups by the treatment of CARV. The results indicated the protective role of CARV on the extracellular $\mathrm{Ca}^{2+}$ influx via the activations of TRPM2 and TRPV4 in the HEK293 cells.

\section{The increases of ADPR-mediated TRPM2 activity and GSK-induced TRPV4 current density were decreased in the SH-SY5Y and transfected HEK293 cells by the treatment of CARV}

The patch-clamp electrophysiology technique is a valuable technique for the investigation of the cation channel, including the TRP superfamily members. The patch-clamp technique was also used in the HEK293 and SH-SY5Y cells for the experiments of TRPM2 and TRPV4 (Shi et al. 2004; Butenko et al. 2012). As the fourth step in the current study, I aimed to further test the changes via the whole cell patchclamp technique in the SH-SY5Y cells. Patch-clamp results of the TRPM2 and TRPV4 currents are shown in Figs. 5 and 6, respectively. Without ADPR (Fig. 5a) and GSK (Fig. 6a) stimulation in the SH-SY5Y, there were limited currents of TRPM2 and TRPV4 in the cells. However, the TRPM2 and TRPV4 was activated by the stimulation of cytosolic ADPR (1 mM) (Fig. 5b and b (I-V) and GSK (100 nM) (Fig. 6b and
$\mathrm{b}(\mathrm{I}-\mathrm{V}))$. The mean activation times of TRPM2 and TRPV4 in the SH-SY5Y cells were $1.57 \pm 0.29$ and $1.01 \pm 0.08 \mathrm{~min}$, respectively. The current densities of TRPM2 were higher in the group of ADPR $(90.38 \mathrm{pA} / \mathrm{pF})$ than in the group of Cntr (3.46 pA/pF) (Figs. 5c and e) ( $\mathrm{p} \leq 0.05)$. The current densities of TRPV4 were also higher in the group of GSK (72.85 pA/pF) than in the group of Cntr $(2.85 \mathrm{pA} / \mathrm{pF})$ (Figs. $6 \mathrm{~b}$ and $\mathrm{f}$ ) ( $\mathrm{p} \leq 0.05)$. The current density of TRPM2 was lower in the groups of ADPR+ACA (13.13 pA/pF), ADPR+CARV 50 (38.25 pA/pF), and CARV 100 (6.32 pA/ $\mathrm{pF})$ than in the group of ADPR $(\mathrm{p} \leq 0.05)$ (Fig. 5c). The current density of TRPV4 was also lower in the groups of GSK+RuRe (15.05 pA/pF) and GSK+CARV (12.16 pA/pF) than in the group of GSK ( $\mathrm{p} \leq 0.05$ ) (Figs. $6 \mathrm{c}$ and $\mathrm{d}$ ). By the pretreatment of CARV $(1 \mathrm{~h})$, there was limited increase in the TRPM2 (Fig. 5d and e) and TRPV4 (the data are not shown) currents after the ADPR and GSK stimulation, respectively. The mean densities of TRPM2 currents were significantly ( $\mathrm{p} \leq 0.05)$ lower in the CARV $(1 \mathrm{~h})+$ ADPR (4.36 $\mathrm{pA} / \mathrm{pF}$ ) group as compared to the group of ADPR $(90.38 \mathrm{pA} / \mathrm{pF})(\mathrm{p} \leq 0.05)$.

The modulator action of CARV was tested in the absence (HEK293) or presence of TRPM2 (HEK293 ${ }^{\mathrm{M} 2}$ ) and TRPV4 $\left(\mathrm{HEK} 293^{\mathrm{V} 4}\right)$ in the HEK293 cells. There were limited currents of TRPM2 (Fig. 5f and i) and TRPV4 (Fig. 6e and f) in the HEK293 cells after ADPR and GSK stimulation. However, I observed TRPM 2 current in the HEK $293^{\mathrm{M} 2}$ cells after the ADPR stimulation (Fig. 5g) and the current density of TRPM2 was significantly ( $\leq \leq 0.05$ ) higher in the HEK293 ${ }^{\mathrm{M} 2}$ cells $(83.63 \mathrm{pA} / \mathrm{pF})$ than in the HEK293 cells (2.72 pA/pF) (Fig. 5i). However, the currents of TRPM2 was fully inhibited by the preincubations of ACA and CARV (1 h) (Fig. 5h) and the current density of TRPM2 in the HEK $293^{\mathrm{M} 2}$ cell was lower in the group of ADPR+ACA (14.94 pA/pF) and CARV (1 h) + ADPR (3.72 pA/pF) than in the group of ADPR (83.63 pA/pF) (Fig. 5i) $(\mathrm{p} \leq 0.05)$. The protective action of CARV on the TRPV4 currents was observed in the HEK $293^{\mathrm{V} 4}$ cells after the preincubation of CARV (1 h) (Data are not shown). The data of patchclamp further indicated the modulator action of CARV on the ADPR and GSK-mediated excessive $\mathrm{Ca}^{2+}$ influx via the activations of TRPM2 and TRPV4 in the SH-SY5Y and HEK293 transfected cells.

\section{The pretreatments of CARV modulated $\mathrm{H}_{2} \mathrm{O}_{2}$ and GSK-mediated changes of cell viability, CASP-3, CASP-9, and apoptosis levels in the SH-SY5Y cells}

Several physiological and pathophysiological actions in the neurons and cells are performed by the increase of $\mathrm{cCa}^{2+}$ concentration. One of the pathophysiological action in the cells is programmed cell death (apoptosis). The apoptosis is induced by the activation of procaspases such as CASP-3 

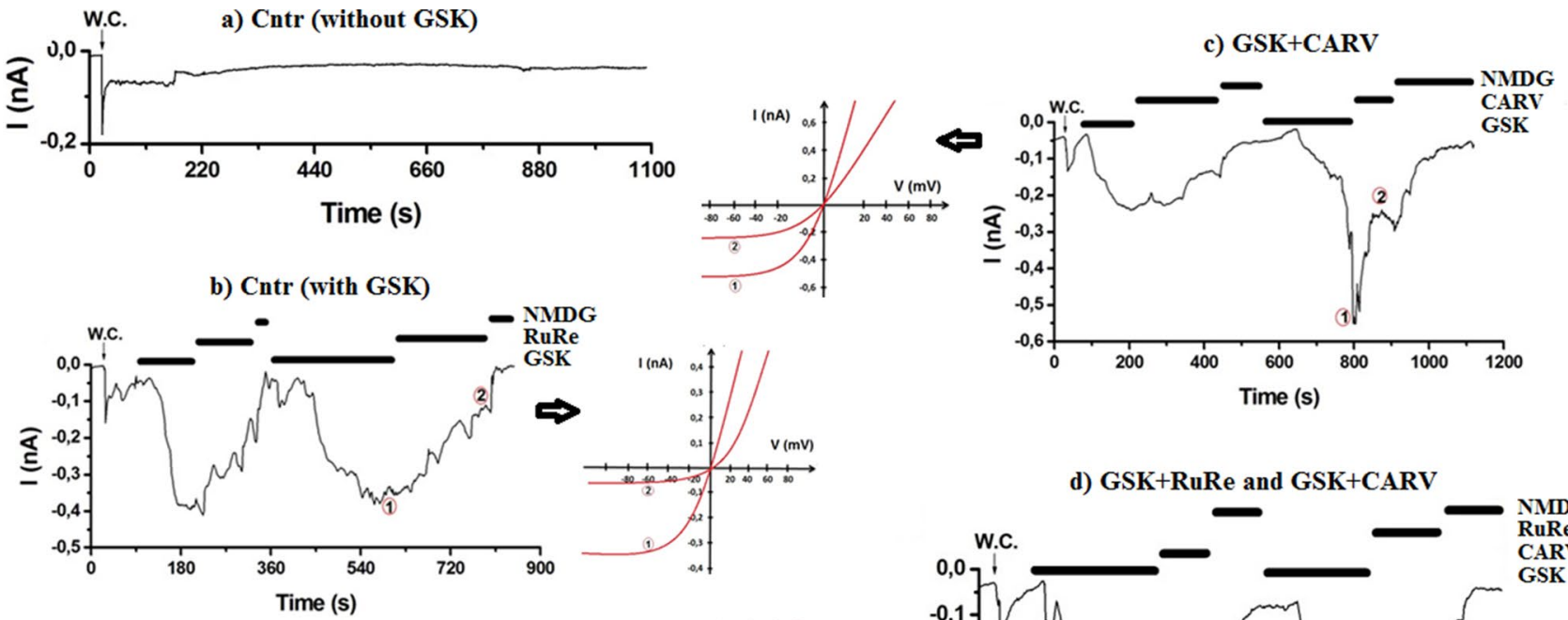
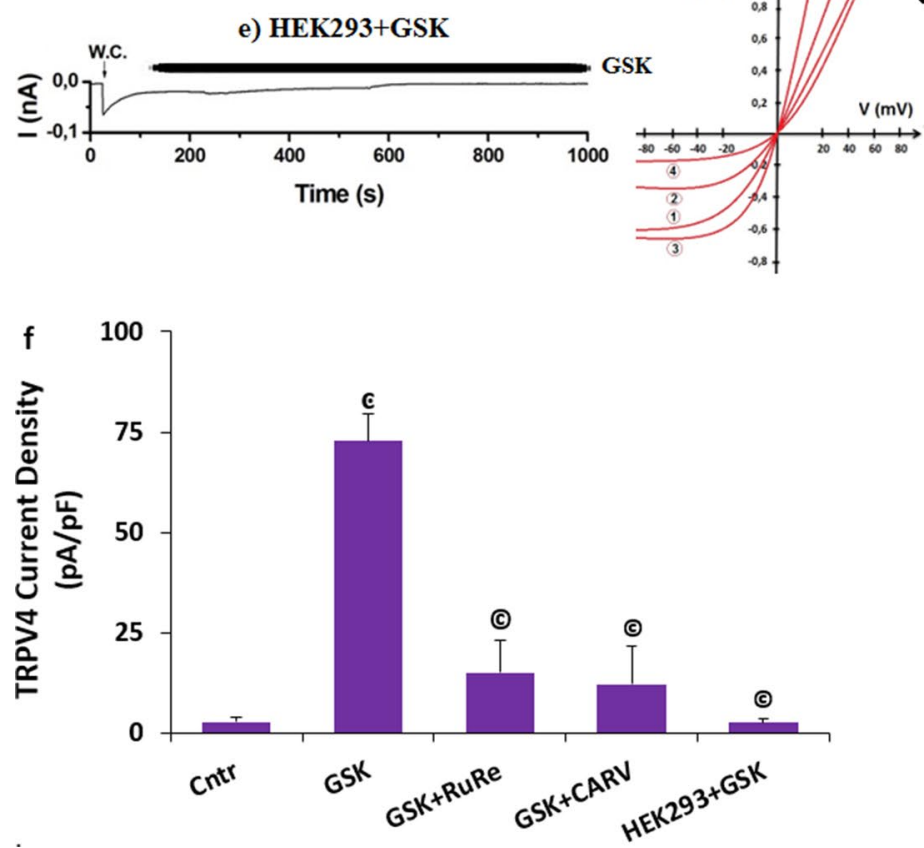

Fig. 6 GSK induced increase of TRPV4 current densities $(\mathrm{pA} / \mathrm{pF})$ in the SH-SY5Y cells but not in the HEK293 cells. The modulator role of CARV. (Mean \pm STD and $n=3-6$ ). The TRPM2 currents were induced in the SH-SY5Y cells by the stimulation of GSK $(100 \mathrm{nM})$, but they were blocked by the treatment of CARV $(100 \mu \mathrm{M})$. W.C.: The record of whole cell. a. Cntr (without GSK). b. Cntr (with GSK

and CASP-9. The $\mathrm{H}_{2} \mathrm{O}_{2}$ and GSK-mediated increases of CASP-3, CASP-9, and apoptosis via the activation of TRPM2 and TRPV4 were reported in the mice hippocampus, myocardial, and SH-SY5Y cells [30,41-43]. In addition, the levels of cell viability were decreased in the SHSY5Y cells by the treatment of $\mathrm{H}_{2} \mathrm{O}_{2}$ and GSK (Jie et al. 2015; Dong et al. 2017; Tian et al. 2017; Wang et al. 2019; Akyuva and Nazıroğlu 2020). After observing the $\mathrm{H}_{2} \mathrm{O}_{2}$ and and RuRe). c. GSK+CARV $(100 \mu \mathrm{M})$. d. GSK + RuRe and GSK + CARV (1 h). e. HEK293 cells + ADPR (without TRPM2). f. The mean currents densities of TRPM2 in the SH-SY5Y and HEK293 cells after the treatments of GSK, RuRe, and CARV ( ${ }^{6} \mathrm{p} \leq 0.05$ vs. Cntr. $\odot \mathrm{p} \leq 0.05$ vs. GSK)

GSK-mediated increase of $\mathrm{cCa}^{2+}$ concentration via the activations of TRPM2 and TRPV4, I suspected the changes of CASP-3, CASP -9, cell viability, and apoptosis levels in the SH-SY5Y cells. The activities of CASP-3 (Fig. 7a), CASP-9 (Fig. 7b), and the levels of apoptosis (Fig. 7e) were increased in the groups of $\mathrm{H}_{2} \mathrm{O}_{2}$ and GSK by the treatments of $\mathrm{H}_{2} \mathrm{O}_{2}$ and GSK, although their activities and levels were diminished in the groups of $\mathrm{H}_{2} \mathrm{O}_{2}+\mathrm{CARV}$ and GSK + CARV 
Fig. 7 The pretreatment of CARV (100 $\mu \mathrm{M}$ for $24 \mathrm{~h})$ modulated GSK (100 $\mathrm{nM}$ for $60 \mathrm{~min}$ ) and $\mathrm{H}_{2} \mathrm{O}_{2}$ (1 mM for $60 \mathrm{~min}$ )mediated increase of cell viability, caspase -3 (CASP-3), caspase -9 (CASP-9), and apoptosis levels in the SH-SY5Y cells. (Mean \pm STD and $n=6$ ). The CASP-3 (a), CASP-9 (b), apoptosis (c), and cell viability (d) levels were analyzed in the automatic microplate reader by Ac-DEVD-AMC substrate, Ac-LEHD-AMC substrate, commercial kit, and MTT, respectively. (" $\mathrm{p} \leq 0.05$ vs. control (Cntr) and MLT groups. $\times \mathrm{p} \leq 0.05$ vs. $\mathrm{H}_{2} \mathrm{O}_{2}$ and $\mathrm{GSK}$ groups)
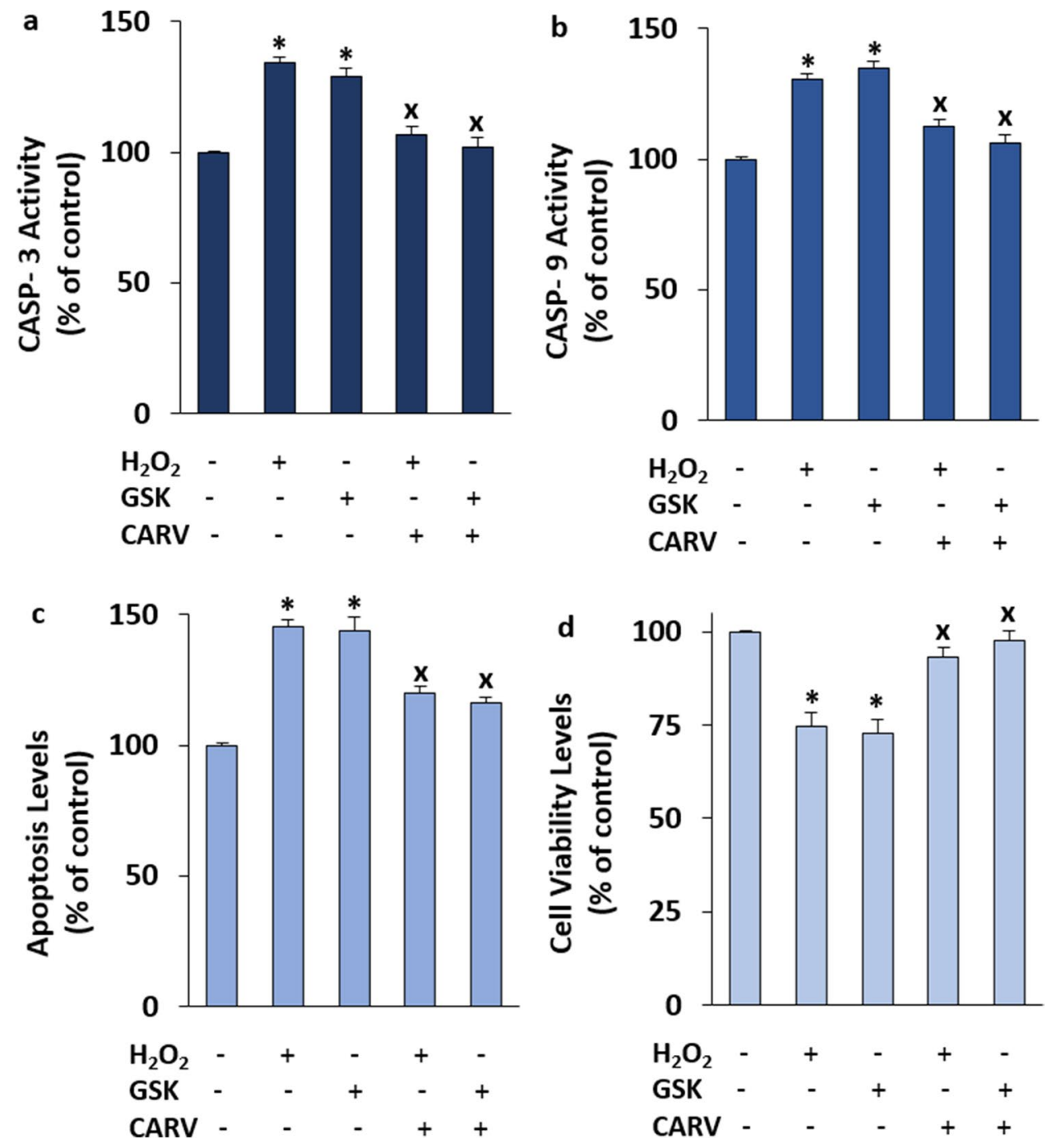

by the treatment of CARV ( $\mathrm{p} \leq 0.05$ ). I observed similar modulator action of CARV on the levels of cell viability in the SH-SY5Y cells (Fig. 7d) and the levels of cell viability were lower in the groups of $\mathrm{H}_{2} \mathrm{O}_{2}$ and GSK as compared to the groups of Cntr. However, the levels of cell viability were increased in the groups of $\mathrm{H}_{2} \mathrm{O}_{2}+\mathrm{CARV}$ and GSK + CARV by the treatment of CARV $(\mathrm{p} \leq 0.05)$.

\section{The treatment of CARV decreased $\mathrm{H}_{2} \mathrm{O}_{2}$ and GSK-induced increases of cell death (PI/ Hoechst) rate in the SH-SY5Y cells}

Accumulating evidence indicates that the $\mathrm{H}_{2} \mathrm{O}_{2}$ and GSKinduced increase of apoptosis via the increase of CASP-3 and CASP-9 results in cell death (Jie et al. 2015; Dong et al. 2017; Tian et al. 2017; Wang et al. 2019; Akyuva and Nazıroğlu 2020). The stain of propidium iodide (PI) cannot pass the nucleus of live cells, Hence, it is permeable to the
DNAs of plasma membrane permeabilized cells. However, the stain of Hoechst dye is permeable to the DNAs of plasma membrane intact cells. The stains of PI/Hoechst were used in the TRPM2 and TRPV4 experiments in several cells (Shahidullah et al. 2012; Akyuva and Nazıroğlu 2020). After observing the increase of programmed cell death, I suspected the increase of cell death rate. I captured the images of black/white (bright field, BF) (Fig. 8a), were captured by using a camera with high resolution, although the images of red/blue (PI/ Hoechst) (Fig. 8b) and 2.5D (Fig. 8c) were captured in LSM800 microscope. In the present data, the rates of death neuron (Fig. 8d) in the groups of $\mathrm{H}_{2} \mathrm{O}_{2}$ and GSK were higher than those in the groups of $\mathrm{Cntr}(\mathrm{p} \leq 0.05)$. However, the treatments of CARV acted modulator role on the rates in the SH-SY5Y cells. The levels of the rates of death SH-SY5Y cells were significantly $(\mathrm{p} \leq 0.05)$ lower in the groups of $\mathrm{H}_{2} \mathrm{O}_{2}+\mathrm{CARV}$ and $\mathrm{GSK}+\mathrm{CARV}$ as compared to the groups of $\mathrm{H}_{2} \mathrm{O}_{2}$ and GSK ( $\left.\leq \leq 0.05\right)$. 

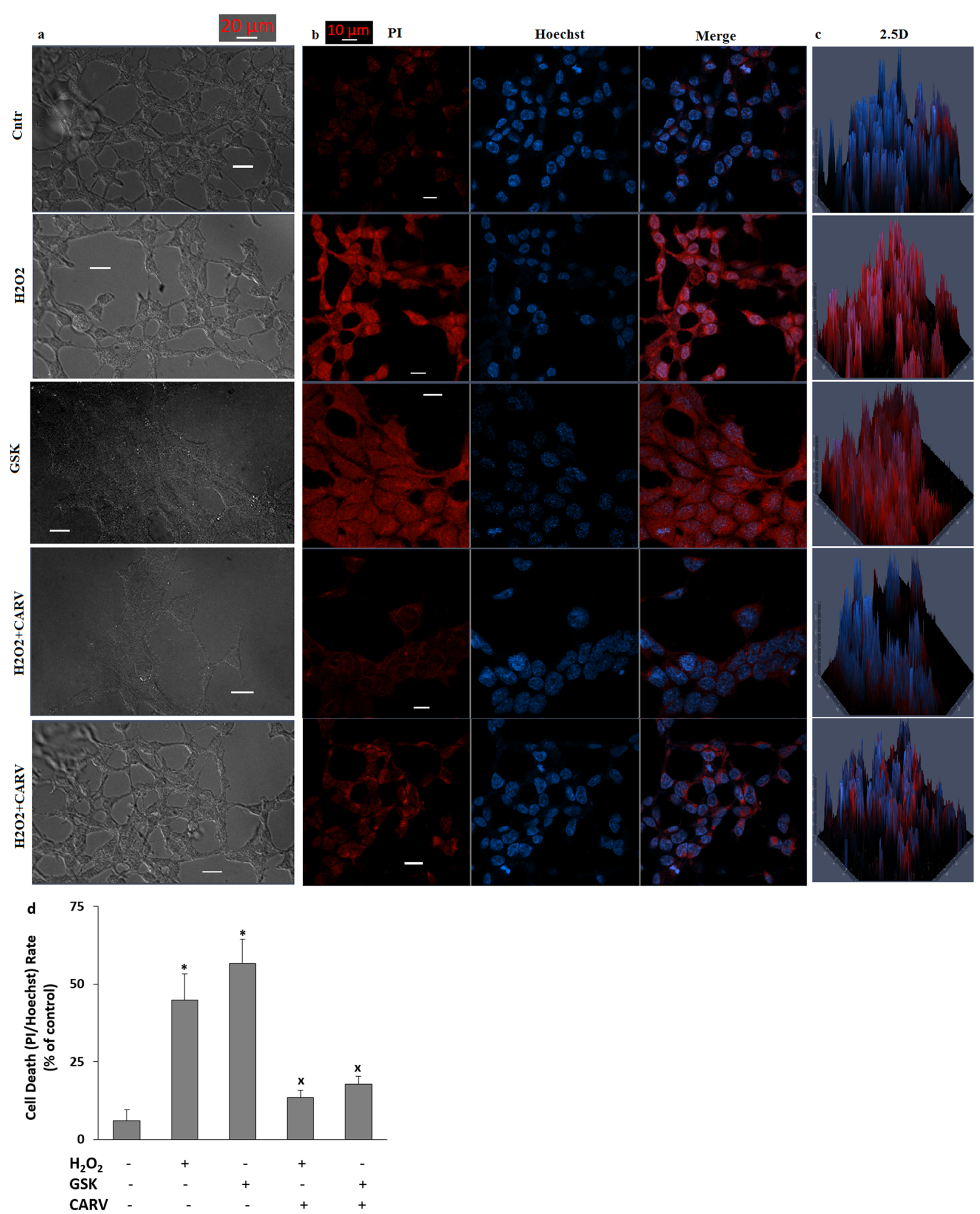
4Fig. 8 The pretreatment of CARV $(100 \mu \mathrm{M}$ for $24 \mathrm{~h})$ modulated GSK (100 nM for $24 \mathrm{~h})$ and $\mathrm{H}_{2} \mathrm{O}_{2}(1 \mathrm{mM}$ for $24 \mathrm{~h})$-induced increase of SH-SY5Y cell death. (Mean \pm STD and $n=20-25$ ). a. The images of bright field (BF, black-white). b. The images of PI (red and dead cells), Hoechst (blue and live cells), and merge images. c. The $2.5 \mathrm{D}$ images of merges. d. The mean percentage of cell death (PI and Hoechst-positive) cell rates in the five groups. (Objective: $20 \times$. Scala bar: $20 \mu \mathrm{m})$. ( ${ }^{*} \mathrm{p} \leq 0.05 \mathrm{vs}$. control (Cntr) and MLT groups. $\times \mathrm{p} \leq 0.05 \mathrm{vs}$. $\mathrm{H}_{2} \mathrm{O}_{2}$ and GSK groups)

\section{The treatment of CARV decreased $\mathrm{H}_{2} \mathrm{O}_{2}$ and GSK-induced increases of $\mathrm{mROS}$, mitochondrial membrane depolarization $(\Delta \Psi \mathrm{m})$, and cROS levels in the SH-SY5Y cells}

The increase of $\Delta \Psi \mathrm{m}$ is induced in several neurons and cells by the accumulations of $\mathrm{cCa}^{2+}$ into mitochondria (Sensi et al. 2003; Ji et al. 2020). The protective action of CARV on the levels of mROS, apoptosis, and ROS in the cardiomyocyte was reported (Chen et al. 2017). However, there is no data modulator role of CARV on oxidative cytotoxicity via the accumulations of $\mathrm{cCa}^{2+}$ into mitochondria in the SH-SY5Y cells. I postulated that the $\mathrm{H}_{2} \mathrm{O}_{2}$ and GSK-mediated mitochondrial (mROS) and cROS are induced by the activation of TRPM2 and TRPV4. I imaged $\mathrm{H}_{2} \mathrm{O}_{2}$ and GSK-induced mROS generation (Fig. 9a, b, and c), JC-1 (Fig. 9a, b, and d), and cROS (Fig. 9a, b, and e) by using MitoTracker Red CM-H2Xros, JC-1, and DCFH-DA stains, respectively. The results of images indicated that increased levels of mROS, $\Delta \Psi \mathrm{m}$, and cROS are observed upon $\mathrm{H}_{2} \mathrm{O}_{2}$ and GSK treatments $(\mathrm{p} \leq 0.05)$. I further evaluated the modulator actions of CARV on the levels of mROS, $\Delta \Psi \mathrm{m}$, and cROS in the SH-SY5Y cells. Importantly, the treatment of CARV (RuRe) prevented increases of levels of mROS, $\Delta \Psi \mathrm{m}$, and cROS (Fig. 9) $(\mathrm{p} \leq 0.05)$. The involvements of CARV on the $\mathrm{H}_{2} \mathrm{O}_{2}$ and GSK-induced oxidative neurodegeneration and apoptosis via the activations of TRPM2 and TRPV4 in the SHSY5Y were confirmed by the results of caspases.

\section{The treatment of CARV reduced $\mathrm{H}_{2} \mathrm{O}_{2}$ and GSK-induced oxidative damage (lipid peroxidation, MDA) via up regulation of glutathione (GSH) and glutathione peroxidase (GSHPx) in the SH-SY5Y cells}

Compared to control, the treatment of $\mathrm{H}_{2} \mathrm{O}_{2}$ and GSK significantly reduced the levels of GSH and GSHPx (Table 1) $(\mathrm{p} \leq 0.05)$. However, the pretreatment of CARV before the treatment of $\mathrm{H}_{2} \mathrm{O}_{2}(1 \mathrm{mM}$ for $1 \mathrm{~h}$ ) and GSK (100 $\mathrm{nM}$ for $1 \mathrm{~h}$ ) markedly enhanced the levels of GSH and GSHPx in comparison to the groups of $\mathrm{H}_{2} \mathrm{O}_{2}$ and GSK ( $\mathrm{p} \leq 0.05$ ). The increase of MDA represents the oxidative damage in the lipids and proteins in the cell membrane (Nazıroğlu 2007). The decrease in the concentration of GSH following $\mathrm{H}_{2} \mathrm{O}_{2}$ and GSK exposure corresponded with increased MDA concentration in the cells $(\mathrm{p} \leq 0.05)$ (Table 1). However, the $\mathrm{H}_{2} \mathrm{O}_{2}$ and GSK-mediated increase of MDA concentrations were fully prevented by the treatment of CARV $(100 \mu \mathrm{M}$ for $24 \mathrm{~h})(\mathrm{p} \leq 0.05)$.

\section{Discussion}

The GSK and $\mathrm{H}_{2} \mathrm{O}_{2}$ induce oxidative stress in neurons (Halliwell 2006; Nazıroğlu 2007; Hong et al. 2016). The activations of TRPM2 and TRPV4 were induced by the $\mathrm{H}_{2} \mathrm{O}_{2}$ and GSK, respectively (Jie et al. 2015, 2016; Ertilav 2019; Akyuva and Nazıroğlu 2020). The activations of TRPM2 and TRPV4 cause oxidative neuronal injury, although their inhibitions cause the decrease of oxidative injury and apoptosis (Jie et al. 2015, 2016; Akyuva and Nazıroğlu 2020). There are no specific antagonists of TRPM2 and TRPV4 channels in the literature. In addition, the present TRPM2 and TRPV4 antagonist chemicals have adverse action in the body cells (Nazıroğlu et al. 2012). The decrease of TRPV4 (GSK) and TRPM2 (ADPR and $\mathrm{H}_{2} \mathrm{O}_{2}$ ) activators-induced neuronal death in the hippocampus of mice were reported after the administration of antioxidants (Hong et al. 2016; Kahya et al. 2017). CARV is a strong antioxidant, and its modulator role on several processes such as free radicals and $\mathrm{Ca}^{2+}$ influx in several cells was reported (Chen et al. 2015; Naeem et al. 2021). At least 11 of 28 subfamilies are activated by oxidative stress (Nazıroğlu et al. 2012). One subfamily of the oxidative stress-dependent activated TRP channel is TRPM7. An antagonist of TRPM7 is CARV (Lipski et al. 2006; Jeong et al. 2020). Hence, the TRPM2 and TRPV4 channels may be modulated in neuronal cell lines by the treatment of CARV. The action of CARV against TRPM2 and TRPV4 activation-induced mROS and apoptosis in the SH-SY5Y and BV-2 microglial cells has not been clarified yet. The present data indicated that (1) CARV inhibited the TRPM2 and TRPV4, and (2) the treatment of CARV attenuated GSK and $\mathrm{H}_{2} \mathrm{O}_{2}$-induced neuronal injury effects via the upregulation of antioxidants (GSH and GSHPx), but downregulation of MDA, mROS, cROS, apoptosis, cell death, and $\mathrm{CCa}^{2+}$.

As a $\mathrm{Ca}^{2+}$ permeable cation channel, the concentration of $\mathrm{CCa}^{2+}$ increases the activation of TRPV4 (Watanabe et al. 2002; Nakagawa et al. 2020). The increase of oxidative stress is caused by the activation of TRPV4. In turn, the increase of oxidative stress results in excessive $\mathrm{Ca}^{2+}$ influx via the activation of TRPV4 in several cells. In the artery endothelial cells, the treatment of TRPV4 agonist stimulated the generation of mROS via the TRPV4-mediated increases of the $\mathrm{cCa}^{2+}$ concentration (Bubolz et al. 2012). In urothelial cells, the increases of $\mathrm{cCa}^{2+}$ concentration and $\mathrm{H}_{2} \mathrm{O}_{2}$ generation by the activation of TRPV4 were also reported (Donkó 

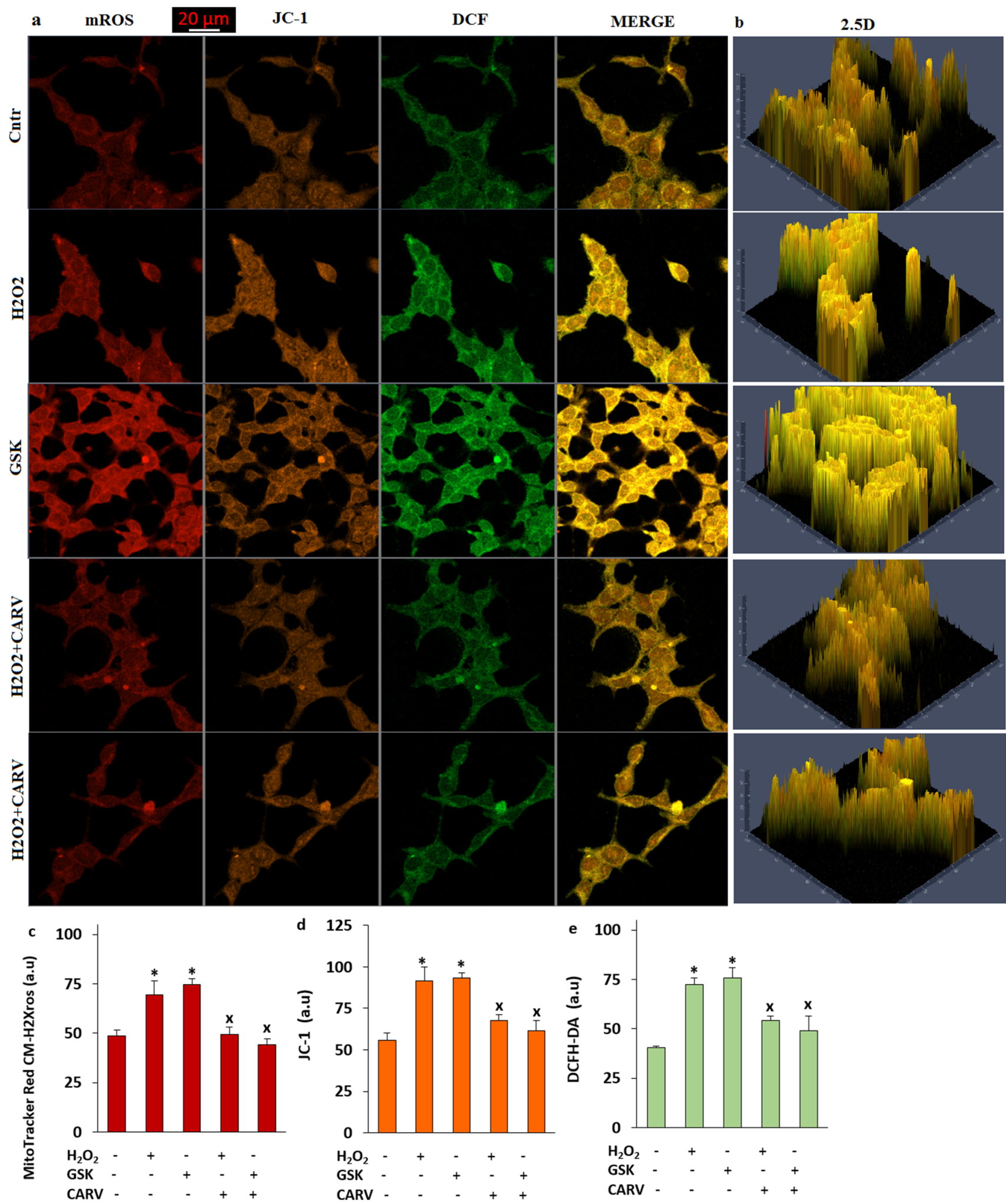

Fig. 9 The pretreatment of CARV $(100 \mu \mathrm{M}$ for $24 \mathrm{~h})$ diminished GSK (100 nM for $1 \mathrm{~h}$ ) and $\mathrm{H}_{2} \mathrm{O}_{2}(1 \mathrm{mM}$ for $1 \mathrm{~h}$ )-induced increase of mROS, $\Delta \Psi \mathrm{m}$, and cROS in the SH-SY5Y cells. (Mean \pm STD and $\mathrm{n}=20-25)$. a. The images of mROS, $\Delta \Psi \mathrm{m}$, and cROS generation in the Cntr, $\mathrm{H}_{2} \mathrm{O}_{2}$, GSK, $\mathrm{H}_{2} \mathrm{O}_{2}+\mathrm{CARV}$, and GSK + CARV groups by using the stains of MitoTracker Red CM-H2Xros, JC-1, and DCFH-
DA, respectively (Objective: $40 \times$ oil. Scala bar: $20 \mu \mathrm{m}$ ). b. The 2.5 images of mROS, $\triangle \Psi \mathrm{m}$, and cROS in the five group. Representative column of the fluorescence intensities of the mROS (c), (d), and DCFH-DA (e). ( $\mathrm{p} \leq 0.05$ vs. Cntr. $\times \mathrm{p} \leq 0.05$ vs. $\mathrm{H}_{2} \mathrm{O}_{2}$ and GSK groups) 
Table 1 Effect of CARV (100 $\mu \mathrm{M}$ for $24 \mathrm{~h}), \mathrm{H}_{2} \mathrm{O}_{2}(1 \mathrm{mM}$ for $1 \mathrm{~h})$, and GSK (100 $\mathrm{nM}$ for $1 \mathrm{~h}$ ) on the concentrations of lipid peroxidation (MDA), glutathione $(\mathrm{GSH})$, and glutathione peroxidase (GSHPx) in the SH-SY5Y cells. (Mean \pm STD and $n=6$ )

\begin{tabular}{|c|c|c|c|c|c|}
\hline Parameters & Control & $\mathrm{H}_{2} \mathrm{O}_{2}$ & GSK & $\mathrm{H}_{2} \mathrm{O}_{2}+\mathrm{CARV}$ & GSK+CARV \\
\hline $\begin{array}{l}\text { MDA } \\
\text { ( } \mu \mathrm{mol} / \mathrm{g} \text { prot.) }\end{array}$ & $20.60 \pm 2.72$ & $29.30 \pm 1.78^{*}$ & $26.90 \pm 0.95^{*}$ & $20.00 \pm 3.36^{* *}$ & $21.40 \pm 1.59^{* *}$ \\
\hline $\begin{array}{l}\text { GSH } \\
(\mu \mathrm{mol} / \mathrm{g} \text { prot.) }\end{array}$ & $15.40 \pm 1.30$ & $12.10 \pm 0.28^{*}$ & $11.40 \pm 0.94^{*}$ & $14.60 \pm 1.13^{* *}$ & $14.00 \pm 0.78^{* *}$ \\
\hline $\begin{array}{l}\text { GSHPx } \\
\text { (IU/g prot.) }\end{array}$ & $23.30 \pm 2.78$ & $20.40 \pm 2.25^{*}$ & $19.80 \pm 1.96^{*}$ & $22.30 \pm 2.79^{* *}$ & $21.60 \pm 2.71^{* *}$ \\
\hline
\end{tabular}

${ }^{*} \mathrm{p} \leq 0.05$ vs. the group of control. ${ }^{* *} \mathrm{p} \leq 0.05$ vs. the groups of $\mathrm{H}_{2} \mathrm{O}_{2}$ and GSK

et al. 2010). In a recent study, ethanol-induced gastric injury in mice was accelerated via the downregulation of superoxide dismutase and GSH, but the upregulation of MDA by the TRPV4 activator (GSK) (Pacheco et al. 2021). The activation of TRPV4 was caused to the oxidative stress in the hippocampus and dorsal root ganglion of mice, although the oxidative stress was diminished by the treatment of antioxidants (Trolox, phenyl- $\alpha$-tert-butyl nitrone, and ARL-17,477) (Hong et al. 2016; Pacheco et al. 2021). In the current study, the activation of TRPV4 was caused to the excessive generation of oxidative stress and overload $\mathrm{Ca}^{2+}$ influx in the SH-SY5Y, BV-2, and HEK $293^{\mathrm{V} 4}$ cells. The modulator role of CARV on several processes such as oxidative stress and $\mathrm{Ca}^{2+}$ influx in several cells was reported (Chen et al. 2015; Naeem et al. 2021). In the current study, the oxidative stress and TRPV4 activation in the SH-SY5Y and HEK293 ${ }^{\mathrm{V} 4}$ cells was decreased via the upregulation of GSHPx and GSH, but the downregulation of MDA, cROS, and mROS by the treatment of CARV.

The TRPM2 is also a $\mathrm{Ca}^{2+}$ permeable cation channels, and it is activated by ADPR and ADPR (Perraud et al. 2001; Hara et al. 2002; Nazıroğlu and Lückhoff 2008). The TRPM2 is inhibited by nonspecific chemicals such as PARP-1 inhibitors, ACA, and 2-APB (Nazıroğlu et al. 2012; Akyuva and Nazıroğlu 2020; Armağan and Nazıroğlu 2021). In addition to the ADPR and $\mathrm{H}_{2} \mathrm{O}_{2}$, the TRPM2 was activated by the depletion of GSH, although it was inhibited by the treatment of GSH (Yıldızhan and Nazıroğlu 2020). The modulator role of CARV treatments on the GSH levels and GSHPx activity in several neuronal cells such as PC12 (Banik et al. 2019) and hippocampus (Guan et al. 2019) was recently reported. The modulator role of CARV on the PARP-1 activity in cancer cells was also reported (Guan et al. 2019). In the current study, the mROS, cROS, and TRPV4 activation in the SH-SY5Y and HEK293 ${ }^{\mathrm{V} 4}$ cells were diminished via the upregulation of GSHPx and GSH by the treatment of CARV. The TRPM2 channels was inhibited in SH-SY5Y cells and mice microglia by the PARP-1 inhibitors (PJ34 and DPQ) (Akyuva and Nazıroğlu 2020; Yıldızhan and Nazıroğlu 2020; Armağan and Nazıroğlu
2021). Similarly, the TRPM2 was inhibited in the SH-SY5Y cells by the PARP-1 inhibitors.

TRPM2 and TRPV4-mediated apoptosis and neuronal death have been confirmed in several neurons, and the activations of TRPM2 and TRPV4 are responsible for neuronal oxidative injury in cerebral ischemic/reperfusion apoptosis via the activation of CASP-3 and CASP-9 pathways Pathania et al. 2013; Jie et al. 2015; Akpınar et al. 20,116). In previous studies, the death of hippocampus was induced in mice by the intracerebroventricular injection of TRPV4 agonist (GSK) (Jie et al. 2015). The increases of $\mathrm{cCa}^{2+}$ via the activations of TRPM 2 and TRPV4 result in the increase of apoptosis and cell death via the increase of CASP-3 and CASP-9 (Jie et al. 2015; Akpınar et al. 2016; Dong et al. 2017). However, the apoptosis and cell death were decreased via the inhibition of CARV in the several neuronal cells by the treatment of CARV (Pathania et al. 2013; Banik et al. 2019; Guan et al. 2019). The present data indicate that the treatments of $\mathrm{H}_{2} \mathrm{O}_{2}$ and GSK via the increases of TRPM2 and TRPV4 activation-mediated $\mathrm{CCa}^{2+}$, ROS, and mROS led to extensive apoptosis in the SH-SY5Y neuronal cell death. CARV, however, effectively reduced the amount of apoptosis and cell death level, although cell viability level was increased by the treatment of CARV. These results of CARV on the apoptosis, neuronal death, CASP-3, and CASP-9 levels in the SH-SY5Y were consistent with findings of previous reports (Jie et al. 2015, 2016; Akpınar et al. 2016; Dong et al. 2017).

Accumulating data suggest that the $\mathrm{H}_{2} \mathrm{O}_{2}$ and GSK-mediated neurodegeneration are induced by the generations of cROS and mROS (Jie et al. 2015, 2016; Nazıroğlu et al. 2020). A main source of cROS and mROS is mitochondria (Nazıroğlu 2007; Carrasco et al. 2018). The overload $\mathrm{Ca}^{2+}$ accumulation into mitochondria results in the increase of oxidant and apoptotic factors via the increase $\Delta \Psi \mathrm{m}$ (Hara et al. 2002; Nazıroğlu et al. 2012). The treatments of ADPR and GSK in several cells induced excessive mROS and cROS generations via upregulation of $\Delta \Psi \mathrm{m}$ (Jie et al. 2015, 2016; Akyuva and Nazıroğlu 2020; Armağan and Nazıroğlu 2021). The modulator role of CARV on the generation ADPR in the cancer cells was reported (Arunasree 2010; 
Pathania et al. 2013). TRPM7 inhibitor role of CARV was reported in neurons (Parnas et al. 2009; Chen et al. 2015; Jeong et al. 2020). Contrary, the TRPV 3 and TRPA1 activator role of CARV was reported in the transfected HEK293 cells and dorsal root ganglions (Kumamoto and Fujita 2016; Schenk et al. 2019). To examine whether mROS, cROS, and $\triangle \Psi \mathrm{m}$ were involved in ADPR and GSK-induced increases of TRPM2 and TRPV4 channel currents, I examined the effects of antioxidant CARV. The results in the SH-SY5Y cells are exemplified by the action of CARV, which totally inhibited the augmentation of ADPR-mediated TRPV1 currents, while unpresented of TRPM2 and TRPV4 in the HEK293 cells unaffected. Furthermore, this modulator action of CARV was also observed on the mROS and cROS in the SH-SY5Y cells. There is no report of CARV on the ADPR and GSK-mediated increases of mROS, cROS, and $\Delta \Psi \mathrm{m}$ via the decrease of TRPM 2 and TRPV4 activations and currents in neuronal cells. However, these findings of mROS, cROS, and $\Delta \Psi \mathrm{m}$ are in accordance with the suggestion of TRPM 2 and voltage gated $\mathrm{Ca}^{2+}$ channels that $\mathrm{ADPR} / \mathrm{H}_{2} \mathrm{O}_{2}$ and GSK-mediated the accumulation of $\mathrm{Ca}^{2+}$ into mitochondria increases cROS and mROS generation from mitochondria (Jie et al. 2015, 2016; Akyuva and Nazıroğlu 2020; Armağan and Nazıroğlu 2021).

In conclusion, the present data provide the first evidence that the ADPR $/ \mathrm{H}_{2} \mathrm{O}_{2}$-induced TRPM2 and GSK-mediated TRPV4 activations were inhibited by the treatment of CARV. The enhanced $\mathrm{H}_{2} \mathrm{O}_{2}$ and GSK-mediated adverse actions such as mROS and cROS were involved in TRPM2 and TRPV4-induced SH-SY5Y neuronal injury and death, although the adverse actions were modulated in the cells by the inhibition of TRPM2 and TRPV4. In addition, the treatment of CARV in the SH-SY5Y, BV-2, and transfected HEK293 cells reversed the $\mathrm{H}_{2} \mathrm{O}_{2}$ and GSK-induced mitochondrial oxidant and apoptotic actions via the inhibition of TRPM2 and TRPV4 and upregulation of glutathione redox system (Graphical Abstract). The present data indicate a novel treatment strategy for preventing $\mathrm{H}_{2} \mathrm{O}_{2}$ and GSK-mediated oxidative neurodegeneration via inhibition of TRPM2 and TRPV4 in the neuronal cells.

Supplementary Information The online version contains supplementary material available at https://doi.org/10.1007/s11011-021-00887-1.

Acknowledgements The authors wish thanks to technician Fatih Şahin and Halil Kavas (BSN Health, Analyses, Innov., Consult., Org., Agricul., Industry LTD., Isparta, Turkey) for helping the patch-clamp analyses.

Author contributions Dr. Nazıroğlu reviewed the current literature, and designed the project. He performed patch clamp and spectrofluorometer analyses. He approved the final manuscript as submitted.

Funding This study was carried out with financial support from BSN Health, Analyses, Innov., Consult., Org., Agricul., Industry LTD. (Göller Bölgesi Teknokenti, Isparta, Turkey). (Project No: 2021-06).
Data availability The present analyses were performed in BSN Health, Analyses, Innovation, Consultancy, Organization, Agriculture, and Industry Ltd, (Göller Bölgesi Teknokenti, Isparta, Turkey) and they are available from the Dr. M. Nazıroğlu on reasonable request. All graphics including graphical abstract in the manuscript were prepared by Dr. M Nazıroğlu.

\section{Declarations}

Ethics approval This article does not contain any data with human and animal participants performed by the author. The author has no ethical conflicts to disclose.

Informed consent Not applicable.

Conflicting interests The author has no conflicts of interest to declare.

\section{References}

Akpınar H, Nazıroğlu M, Övey İS, Çiğ B, Akpınar O (2016) The neuroprotective action of dexmedetomidine on apoptosis, calcium entry and oxidative stress in cerebral ischemia-induced rats: Contribution of TRPM2 and TRPV1 channels. Sci Rep 6:37196. https:// doi.org/10.1038/srep37196

Akyuva Y, Nazıroğlu M (2020) Resveratrol attenuates hypoxia-induced neuronal cell death, inflammation and mitochondrial oxidative stress by modulation of TRPM2 channel. Sci Rep 10(1):6449. https://doi.org/10.1038/s41598-020-63577-5

Armağan HH, Nazıroğlu M (2021) Curcumin attenuates hypoxiaInduced oxidative neurotoxicity, apoptosis, calcium, and zinc ion influxes in a neuronal cell line: Involvement of TRPM2 channel. Neurotox Res 39(3):618-633. https://doi.org/10.1007/ s12640-020-00314-w

Arunasree KM (2010) Anti-proliferative effects of carvacrol on a human metastatic breast cancer cell line, MDA-MB 231. Phytomedicine 17(8-9):581-588. https://doi.org/10.1016/j.phymed. 2009.12.008

Badr H, Kozai D, Sakaguchi R, Numata T, Mori Y (2016) Different Contribution of Redox-Sensitive Transient Receptor Potential Channels to Acetaminophen-Induced Death of Human Hepatoma Cell Line. Front Pharmacol 7:19. https://doi.org/10. 3389/fphar.2016.00019

Banik S, Akter M, Corpus Bondad SE, Saito T, Hosokawa T, Kurasaki M (2019) Carvacrol inhibits cadmium toxicity through combating against caspase dependent/independent apoptosis in PC12 cells. Food Chem Toxicol 134:110835. https://doi.org/10. 1016/j.fct.2019.110835

Bao L, Chen SJ, Conrad K et al (2016) Depletion of the human ion channel TRPM2 in neuroblastoma demonstrates its key role in cell survival through modulation of mitochondrial reactive oxygen species and bioenergetics. J Biol Chem 291(47):2444924464. https://doi.org/10.1074/jbc.M116.747147

Bollimuntha S, Singh BB, Shavali S, Sharma SK, Ebadi M (2005) TRPC1-mediated inhibition of 1-methyl-4-phenylpyridinium ion neurotoxicity in human SH-SY5Y neuroblastoma cells. J Biol Chem 280(3):2132-2140. https://doi.org/10.1074/jbc. M407384200

Bubolz AH, Mendoza SA, Zheng X, Zinkevich NS, Li R, Gutterman DD, Zhang DX (2012) Activation of endothelial TRPV4 channels mediates flow-induced dilation in human coronary arterioles: role of $\mathrm{Ca} 2+$ entry and mitochondrial ROS signaling. Am 
J Physiol Heart Circ Physiol 302(3):H634-H642. https://doi. org/10.1152/ajpheart.00717.2011

Butenko O, Dzamba D, Benesova J, Honsa P, Benfenati V, Rusnakova V et al (2012) The increased activity of TRPV4 channel in the astrocytes of the adult rat hippocampus after cerebral hypoxia/ischemia. PLoS One 7(6):e39959. https://doi.org/10. 1371/journal.pone.0039959

Carrasco C, Nazıroğlu M, Rodríguez AB, Pariente JA (2018) Neuropathic Pain: Delving into the Oxidative Origin and the Possible Implication of Transient Receptor Potential Channels. Front Physiol 9:95. https://doi.org/10.3389/fphys.2018.00095

Chen W, Xu B, Xiao A, Liu L, Fang X, Liu R et al (2015) TRPM7 inhibitor carvacrol protects brain from neonatal hypoxicischemic injury. Mol Brain 8:11. https://doi.org/10.1186/ s13041-015-0102-5

Chen Y, Ba L, Huang W, Liu Y, Pan H, Mingyao E et al (2017) Role of carvacrol in cardioprotection against myocardial ischemia/ reperfusion injury in rats through activation of MAPK/ERK and Akt/eNOS signaling pathways. Eur J Pharmacol 796:90-100. https://doi.org/10.1016/j.ejphar.2016.11.053

de la Monte SM, Neely TR, Cannon J, Wands JR (2000) Oxidative stress and hypoxia-like injury cause Alzheimer-type molecular abnormalities in central nervous system neurons. Cell Mol Life Sci 57(10):1471-1481. https://doi.org/10.1007/PL00000630

Dong Q, Li J, Wu QF, Zhao N, Qian C, Ding D et al (2017) Blockage of transient receptor potential vanilloid 4 alleviates myocardial ischemia/reperfusion injury in mice. Sci Rep 7:42678. https:// doi.org/10.1038/srep42678

Donkó A, Ruisanchez E, Orient A, Enyedi B, Kapui R, Péterfi Z et al (2010) Urothelial cells produce hydrogen peroxide through the activation of Duox1. Free Radic Biol Med 49(12):2040-2048. https://doi.org/10.1016/j.freeradbiomed.2010.09.027

Dringen R (2000) Metabolism and functions of glutathione in brain. Prog Neurobiol 62(6):649-671. https://doi.org/10.1016/S03010082(99)00060-X

Du J, Wong WY, Sun L, Huang Y, Yao X (2012) Protein kinase $\mathrm{G}$ inhibits flow-induced $\mathrm{Ca} 2+$ entry into collecting duct cells. J Am Soc Nephrol 23(7):1172-1180. https://doi.org/10.1681/ ASN.2011100972

Ertilav K (2019) Pregabalin protected cisplatin-induced oxidative neurotoxicity in neuronal cell line. J Cell Neurosci Oxid Stress 11(1):815-824. https://doi.org/10.37212/jcnos.653500

Espino J, Bejarano I, Paredes SD, González D, Barriga C, Reiter RJ et al (2010) Melatonin counteracts alterations in oxidative metabolism and cell viability induced by intracellular calcium overload in human leucocytes: changes with age. Basic Clin Pharmacol Toxicol 107(1):590-597. https://doi.org/10.1111/j.1742-7843. 2010.00546.x

Fonfria E, Marshall IC, Benham CD, Boyfield I, Brown JD, Hill K et al (2004) TRPM2 channel opening in response to oxidative stress is dependent on activation of poly(ADP-ribose) polymerase. $\mathrm{Br} \mathbf{J}$ Pharmacol 143(1):186-192

Guan X, Li X, Yang X, Yan J, Shi P, Ba L, Cao Y, Wang P (2019) The neuroprotective effects of carvacrol on ischemia/reperfusioninduced hippocampal neuronal impairment by ferroptosis mitigation. Life Sci 235:116795. https://doi.org/10.1016/j.lfs.2019. 116795

Guse AH (2015) Calcium mobilizing second messengers derived from NAD. Biochim Biophys Acta 1854(9):1132-1137. https://doi.org/ 10.1016/j.bbapap.2014.12.015

Halliwell B (2006) Oxidative stress and neurodegeneration: where are we now? J Neurochem 97(6):1634-1658. https://doi.org/10. 1111/j.1471-4159.2006.03907.x

Hara Y, Wakamori M, Ishii M, Maeno E, Nishida M, Yoshida T et al (2002) LTRPC2 Ca2+-permeable channel activated by changes in redox status confers susceptibility to cell death. Mol Cell 9(1):163-173. https://doi.org/10.1016/S1097-2765(01)00438-5

Hong Z, Tian Y, Yuan Y, Qi M, Li Y, Du Y et al (2016) Enhanced oxidative stress is responsible for TRPV4-induced neurotoxicity. Front Cell Neurosci 10:232. https://doi.org/10.3389/fncel.2016. 00232

Islam MT (2017) Oxidative stress and mitochondrial dysfunctionlinked neurodegenerative disorders. Neurol Res 39(1):73-82. https://doi.org/10.1080/01616412.2016.1251711

Javed H, Meeran MFN, Jha NK, Ojha S (2021) Carvacrol, a plant metabolite targeting viral protease $\left(\mathrm{M}^{\mathrm{pro}}\right)$ and ACE2 in host cells can be a possible candidate for COVID-19. Front Plant Sci 11:601335. https://doi.org/10.3389/fpls.2020.601335

Jeong JH, Lee SH, Kho AR, Hong DK, Kang DH, Kang BS et al (2020) The Transient Receptor Potential Melastatin 7 (TRPM7) inhibitors suppress seizure-induced neuron death by inhibiting zinc neurotoxicity. Int J Mol Sci 21(21):7897. https://doi.org/10.3390/ijms2 1217897

Ji SG, Medvedeva YV, Weiss JH (2020) $\mathrm{Zn}^{2+}$ entry through the mitochondrial calcium uniporter is a critical contributor to mitochondrial dysfunction and neurodegeneration. Exp Neurol 325:113161. https://doi.org/10.1016/j.expneurol.2019.113161

Jie P, Hong Z, Tian Y, Li Y, Lin L et al (2015) Activation of transient receptor potential vanilloid 4 induces apoptosis in hippocampus through downregulating PI3K/Akt and upregulating p38 MAPK signaling pathways. Cell Death Dis 6(6):e1775. https://doi.org/ 10.1038/cddis.2015.146

Jie P, Lu Z, Hong Z, Li L, Zhou L, Li Y et al (2016) Activation of transient receptor potential vanilloid 4 is involved in neuronal injury in middle cerebral artery occlusion in mice. Mol Neurobiol 53(1):8-17. https://doi.org/10.1007/s12035-014-8992-2

Kahya MC, Nazıroğlu M, Övey İS (2017) Modulation of diabetesinduced oxidative Stress, apoptosis, and $\mathrm{Ca}(2+)$ entry through TRPM2 and TRPV1 channels in dorsal root ganglion and hippocampus of diabetic rats by melatonin and selenium. Mol Neurobiol 54(3):2345-2360. https://doi.org/10.1007/s12035-016-9727-3

Kumamoto E, Fujita T (2016) Differential activation of TRP channels in the adult rat spinal substantia gelatinosa by stereoisomers of plant-derived chemicals. Pharmaceuticals (Basel) 9(3):46. https:// doi.org/10.3390/ph9030046

Lipski J, Park TI, Li D, Lee SC, Trevarton AJ, Chung KK et al (2006) Involvement of TRP-like channels in the acute ischemic response of hippocampal CA1 neurons in brain slices. Brain Res 1077(1):187-199. https://doi.org/10.1016/j.brainres.2006.01.016

Malko P, Ding R, Jiang LH (2021) TRPM2 channel in oxidative stressinduced mitochondrial dysfunction and apoptotic cell death. Adv Protein Chem Struct Biol 125:51-72. https://doi.org/10.1016/bs. apcsb.2020.12.001

McHugh D, Flemming R, Xu SZ, Perraud AL, Beech DJ (2003) Critical intracellular $\mathrm{Ca} 2+$ dependence of transient receptor potential melastatin 2 (TRPM2) cation channel activation. J Biol Chem 278(13):11002-11006. https://doi.org/10.1074/jbc.M210810200

Naeem K, Tariq Al Kury L, Nasar F, Alattar A, Alshaman R et al (2021) Natural dietary supplement, carvacrol, alleviates LPSinduced oxidative stress, neurodegeneration, and depressive-like behaviors via the Nrf2/HO-1 pathway. J Inflamm Res 14:13131132. https://doi.org/10.2147/JIR.S294413

Nakagawa F, Higashi S, Ando E, Ohsumi T, Watanabe S, Takeuchi H (2020) Modification of TRPV4 activity by acetaminophen. Heliyon 6(1):e03301. https://doi.org/10.1016/j.heliyon.2020.e03301

Nazıroğlu M, Dikici DM, Dursun S (2012) Role of oxidative stress and $\mathrm{Ca}^{2+}$ signaling on molecular pathways of neuropathic pain in diabetes: focus on TRP channels. Neurochem Res 37(10):2065-2075. https://doi.org/10.1007/s11064-012-0850-x 
Nazıroğlu M, Lückhoff A (2008) Effects of antioxidants on calcium influx through TRPM2 channels in transfected cells activated by hydrogen peroxide. J Neurol Sci 270(1-2):152-158. https://doi. org/10.1016/j.jns.2008.03.003

Nazıroğlu M, Öz A, Yıldızhan K (2020) Selenium and neurological diseases: Focus on peripheral pain and TRP channels. Curr Neuropharmacol 18(6):501-517. https://doi.org/10.2174/1570159X18 666200106152631

Nazıroğlu M (2007) New molecular mechanisms on the activation of TRPM2 channels by oxidative stress and ADP-ribose. Neurochem Res 32(11):1990-2001

Özkaya D, Shu X, Nazıroğlu M (2021) Deletion of mitochondrial translocator protein (TSPO) gene decreases oxidative retinal pigment epithelial cell death via modulation of TRPM2 channel. Biology (Basel) 10(5):382. https://doi.org/10.3390/biology 10050382

Pacheco G, Oliveira AP, Noleto IRSG, Araújo AK, Lopes ALF, Sousa FBM et al (2021) Activation of transient receptor potential vanilloid channel 4 contributes to the development of ethanol-induced gastric injury in mice. Eur J Pharmacol 902:174113. https://doi. org/10.1016/j.ejphar.2021.174113

Parnas M, Peters M, Dadon D, Lev S, Vertkin I, Slutsky I, Minke B (2009) Carvacrol is a novel inhibitor of Drosophila TRPL and mammalian TRPM7 channels. Cell Calcium 45(3):300-309. https://doi.org/10.1016/j.ceca.2008.11.009

Pathania AS, Guru SK, Verma MK, Sharma C, Abdullah ST, Malik F et al (2013) Disruption of the PI3K/AKT/mTOR signaling cascade and induction of apoptosis in HL-60 cells by an essential oil from Monarda citriodora. Food Chem Toxicol 62:246-254. https://doi.org/10.1016/j.fct.2013.08.037

Perraud AL, Fleig A, Dunn CA, Bagley LA, Launay P, Schmitz C et al (2001) ADP-ribose gating of the calcium-permeable LTRPC2 channel revealed by Nudix motif homology. Nature 411(6837):595-599. https://doi.org/10.1038/35079100

Saleh J, Peyssonnaux C, Singh KK, Edeas M (2020) Mitochondria and microbiota dysfunction in COVID-19 pathogenesis. Mitochondrion 54:1-7. https://doi.org/10.1016/j.mito.2020.06.008

Sánchez JC, Muñoz LV, Ehrlich BE (2020) Modulating TRPV4 channels with paclitaxel and lithium. Cell Calcium 91:102266. https:// doi.org/10.1016/j.ceca.2020.102266

Schenk SA, Dick F, Herzog C, Eberhardt MJ, Leffler A (2019) Active metabolites of dipyrone induce a redox-dependent activation of the ion channels TRPA1 and TRPV1. Pain Rep 4(3):e720. https:// doi.org/10.1097/PR9.0000000000000720

Sensi SL, Ton-That D, Sullivan PG, Jonas EA, Gee KR, Kaczmarek LK, Weiss JH (2003) Modulation of mitochondrial function by endogenous Zn2+ pools. Proc Natl Acad Sci U S A 100(10):61576162. https://doi.org/10.1073/pnas.1031598100

Sha'fie MSA, Rathakrishnan S, Hazanol IN, Dali MHI, Khayat ME, Ahmad S et al (2020) Ethanol induces microglial cell death via the NOX/ROS/PARP/TRPM2 signalling pathway. Antioxidants (Basel) 9(12):1253. https://doi.org/10.3390/antiox9121253

Shahidullah M, Mandal A, Delamere NA (2012) TRPV4 in porcine lens epithelium regulates hemichannel-mediated ATP release and Na-K-ATPase activity. Am J Physiol Cell Physiol 302(12):C1751C1761. https://doi.org/10.1152/ajpcell.00010.2012

Shi J, Mori E, Mori Y, Mori M, Li J, Ito Y, Inoue R (2004) Multiple regulation by calcium of murine homologues of transient receptor potential proteins TRPC6 and TRPC7 expressed in HEK293 cells. J Physiol 561(Pt 2):415-432. https://doi.org/10.1113/jphys iol.2004.075051

Skrzypski M, Kakkassery M, Mergler S, Grötzinger C, Khajavi N, Sassek M et al (2003) Activation of TRPV4 channel in pancreatic INS-1E beta cells enhances glucose-stimulated insulin secretion via calcium-dependent mechanisms. FEBS Lett 587(19):32813287. https://doi.org/10.1016/j.febslet.2013.08.025

Takata T, Araki S, Tsuchiya Y, Watanabe Y (2020) Oxidative stress orchestrates MAPK and nitric-oxide synthase signal. Int J Mol Sci 21(22):8750. https://doi.org/10.3390/ijms21228750

Tian Y, Qi M, Hong Z, Li Y, Yuan Y, Du Y, Chen L, Chen L (2017) Activation of transient receptor potential vanilloid 4 promotes the proliferation of stem cells in the adult hippocampal dentate gyrus. Mol Neurobiol 54(8):5768-5779. https://doi.org/10.1007/ s12035-016-0113-y

Wang Z, Zhou L, An D, Xu W, Wu C, Sha S et al (2019) TRPV4induced inflammatory response is involved in neuronal death in pilocarpine model of temporal lobe epilepsy in mice. Cell Death Dis 10(6):386. https://doi.org/10.1038/s41419-019-1612-3

Watanabe H, Davis JB, Smart D, Jerman JC, Smith GD, Hayes P et al (2002) Activation of TRPV4 channels (hVRL-2/mTRP12) by phorbol derivatives. J Biol Chem 277(16):13569-13577. https:// doi.org/10.1074/jbc.M200062200

Yıldızhan K, Nazıroğlu M (2020) Glutathione depletion and parkinsonian neurotoxin $\mathrm{MPP}^{+}$-induced TRPM2 channel activation play central roles in oxidative cytotoxicity and inflammation in microglia. Mol Neurobiol 57(8):3508-3525. https://doi.org/10.1007/ s12035-020-01974-7

Publisher's Note Springer Nature remains neutral with regard to jurisdictional claims in published maps and institutional affiliations. 